\title{
Kentsel Dönüşümde Çevresel Sürdürülebilirlik Üzerine Bir Araştırma: Fikirtepe Örneği ${ }^{1}$
}

\author{
Begüm Diker \\ Doğuş Üniversitesi \\ ORCID: 0000-0001-9149-3880
}

Öz

Bu araştırmada, bina üretiminin yoğunlaştı̆̆ı kentsel dönüşüm alanlarından biri olan Fikirtepe (İstanbul) bölgesine odaklanılarak; binalarda çevresel sürdürülebilirlik kriterlerinin ne kadar dikkate alındığı incelenmiştir. Bu kapsamda, Türkiye yerel koşulları için oluşturulmuş ulusal sertifikalardan biri olan ÇEDBİK Konut Sertifikası bir 'değerlendirme aracı' olarak ele alınmıştır. Sertifikada bulunan değerlendirme kriterlerinden çalışma kapsamında incelenmek üzere 'Bütünleşik Yeşil Proje Yönetimi', 'Enerji Kullanımı' ve 'Malzeme ve Kaynak Kullanımı' başlıkları seçilmiştir. Alanda yapım süreci başlamış veya tamamlanmış 10 yeni konut binası üzerinden, sertifikada belirtilen kriterlerin kapsam ve gerekliliklerinin sağlanıp sağlanmadığına dair uygunluk kontrolleri yapılmıştır. Bunun için, anket yöntemi seçilmiş olup; projelere ilişkin proje ekibi ve yüklenici firmalar ile yüz yüze görüşmeler gerçekleştirilmiştir. Elde edilen bulgular grafikler üzerinden yorumlanmıştır.

Sonuç olarak, İstanbul için kentsel dönüşümde pilot bölge niteliğinde olan Fikirtepe'deki yeni konut binalarının, çeoresel sürdürülebilirlik açısından birtakım eksiklikleri olduğu saptanmıştır. Türkiye'nin hazırlamış olduğu ulusal eylem planındaki bina sektörü hedeflerine ulaşılabilmesi için, bu denli büyük ölçekli kentsel dönüşüm alanlarmda öncelikli olmak üzere; yeni binalarm enerji performanslarının iyileştirilmesi gereklidir. Çalışma kapsamında, ulusal konut sertifikastnın yeni konut binaları için zorunlu tutulmasının bu hedeflere ulaşılmasını kolaylaştıracă̆ düşünülmektedir. Ayrıca, enerji anlamında devlet teşviklerinin arttırılması ve Avrupa ülkelerinin enerji verimliliği hedeflerinin ve yönetmeliklerinin örnek alınmasının ötesinde, bina üretim süreçlerindeki denetim mekanizmasının iyileştirilmesi gerekmektedir.

Anahtar Kelimeler: Sürdürülebilirlik, enerji verimliliŭi, Çedbik konut sertifikası, kentsel dönüşüm, Fikirtepe

${ }^{1}$ Bu çalışma, Begüm Diker'in “Kentsel Dönüşüm Kapsamında Konutlarda Ulusal Yeşil Bina Sertifikasının Değerlendirilmesi: Fikirtepe Örneği" başlıkl yüksek lisans tez çalı̧masindan üretilmiştir. 


\title{
A Research on Environmental Sustainability in Urban Transformation: The Case of Fikirtepe
}

\author{
Begüm Diker \\ Doğuş University \\ ORCID: 0000-0001-9149-3880
}

\begin{abstract}
In this research, it has been examined how much environmental sustainability criteria are taken into account via focusing on Fikirtepe district (Istanbul) where building production has become dense. In this context, ÇEDBİK Residential Certificate, which has been generated for the Turkey local conditions has been handled as an "assessment tool." The topics called "Integrated Green Building Management," "Energy Use" and "Material and Resource Use" have been selected for the context of the study. Conformity assessment has been made over ten new residential buildings whose production process has been begun or completed in terms of providing or not the requirements and scope of the determined assessment criteria. For this, questionnaire method has been selected, and face to face interviews have been made with project teams and contractor companies. Acquired findings have been interpreted via graphs.

As a result, it has been determined that new residential buildings in Fikirtepe district, which has the characteristics of the pilot region for urban renewal in Istanbul have deficiencies in terms of environmental sustainability. To be reached the building sector targets that are defined in Turkey national action plan, energy performance of new buildings in urban renewal areas that have such a scale should be improved with priority. In the context of the study, it is considered that making national residential certificate as an obligatory will ease to reach the building sector targets. Beyond enhancing of governmental incentives and taking the regulations and energy efficiency targets of European countries as an example, control mechanisms in the building production processes should need to be improved, too.
\end{abstract}

Keywords: Sustainability, energy efficiency, Çedbik residential certificate, urban transformation, Fikirtepe 


\section{Giriş}

Kentler küresel enerji tüketiminin ve sera gazı emisyonlarının yüzde yetmişinden sorumludur (Prugh \& Renner, 2016). Kentlerdeki insan faaliyetlerine bağlı olarak artış gösteren enerji ve kaynak tüketimi iklim değişikliğini tetiklemektedir. Aynı şekilde, iklim değişikliği nedeniyle enerji tüketimindeki artış ve doğal kaynakların azalması, çevresel anlamda bir tehdit unsuru oluşturmaktadır. Bu 'döngüsel tahribatı' önlemek amacıyla iklim değişikliği ile mücadelede- birçok dünya ülkesi kendi koşullarına özgü hedefler koyarak 'sürdürülebilir bir kent' olma yolunda ilerlemektedir. Bu bağlamda, Economist Intelligence Unit'in 2009 yılında başlattığ 1 'Yeşil Kentler İndeksi' serisi, dünyanın farklı bölgelerindeki kentlerin sürdürülebilirliklerinin değerlendirilmesi ve performans ölçümlerinin yap1labilmesi açısından bir kilometre taşı sayılabilir. Oluşumunda Harvard, Cambridge gibi tanınmış üniversitelerin de bulunduğu, 20'den fazla kuruluşun katkı sağladığı rapora göre; $\mathrm{CO}_{2}$ salımı, enerji, bina, arazi kullanımı, ulaşım, su ve sağlık, atık yönetimi, hava kalitesi ve çevresel yönetişim konularında yapılacak iyileştirmeler ile sürdürülebilir bir kent yaratmanın mümkün olabileceği belirtilmektedir (Siemens, 2010). Yine, Avrupa Birliği'nin ‘UFUK 2020: Akıllı Şehirler' çerçevesinde yürüttüğü hibe programı, 'Sürdürülebilir Kentler', 'Akıllı Binalar', 'Kentsel Dönüşüm', 'İnşaat Sektöründe İnovasyon' gibi birçok tematik alanda proje üretmek isteyen kurum ve araştırmacıları desteklemektedir (Horizon 2020, t.y.).

Türkiye, iklim değişikliği ile mücadele konusunda diğer dünya ülkelerini takip eder niteliktedir. Bu kapsamda yapılan çalışmalardan biri de Çevre ve Şehircilik Bakanlığı'nın 2012 yılında hazırladığı 'İklim Değişikliği Ulusal Eylem Planı (IDEP) 2011-2023' başlıklı rapordur. Bu raporda; enerji, bina, sanayi, ulaştırma, atık vb. sektörlere ilişkin hedefler belirlenmiştir. Özellikle, bina sektörü için belirlenen hedefler arasında, "binalarda yenilenebilir enerji kullanımının arttırılması" ve "yeni yerleşmelerde sera gazı emisyonlarını mevcut yerleşmelere göre \%10 azaltılması" gibi hedefler yer almaktadır (Çevre ve Şehircilik Bakanlığı, 2011). Bu hedeflere ulaşılabilirlik bağlamında, nüfusun artış gösterdiği mega kentlerde enerji verimliliğine yönelik değerlendirmelerin yapılması önem kazanmaktadır. Fakat, Türkiye için bir 'mega kent' sayılan İstanbul özelinde detaylı bir inceleme bulunmamaktadır. 
Bu çalışmanın ilk adımında, enerji verimliliği ve çevreye ilişkin literatür araştırmaları incelenmiştir. Bu kapsamda, Türkiye'de enerji verimliliğine ilişkin güncel yasal mevzuat kısaca açıklanmış olup, binaların enerji performansını iyileştirmeye yönelik ulusal ve uluslararası değerlendirme sistemleri hakkında bilgi verilmiştir. Daha sonra, ulusal bina değerlendirme sistemlerinden biri olan ÇEDBİK Konut Sertifikasına odaklanılarak, çalışma kapsamında incelenecek olan değerlendirme kriterleri detaylı olarak açıklanmıştır. Çalışmanın süreç modeli Şekil 1'de gösterilmiştir:

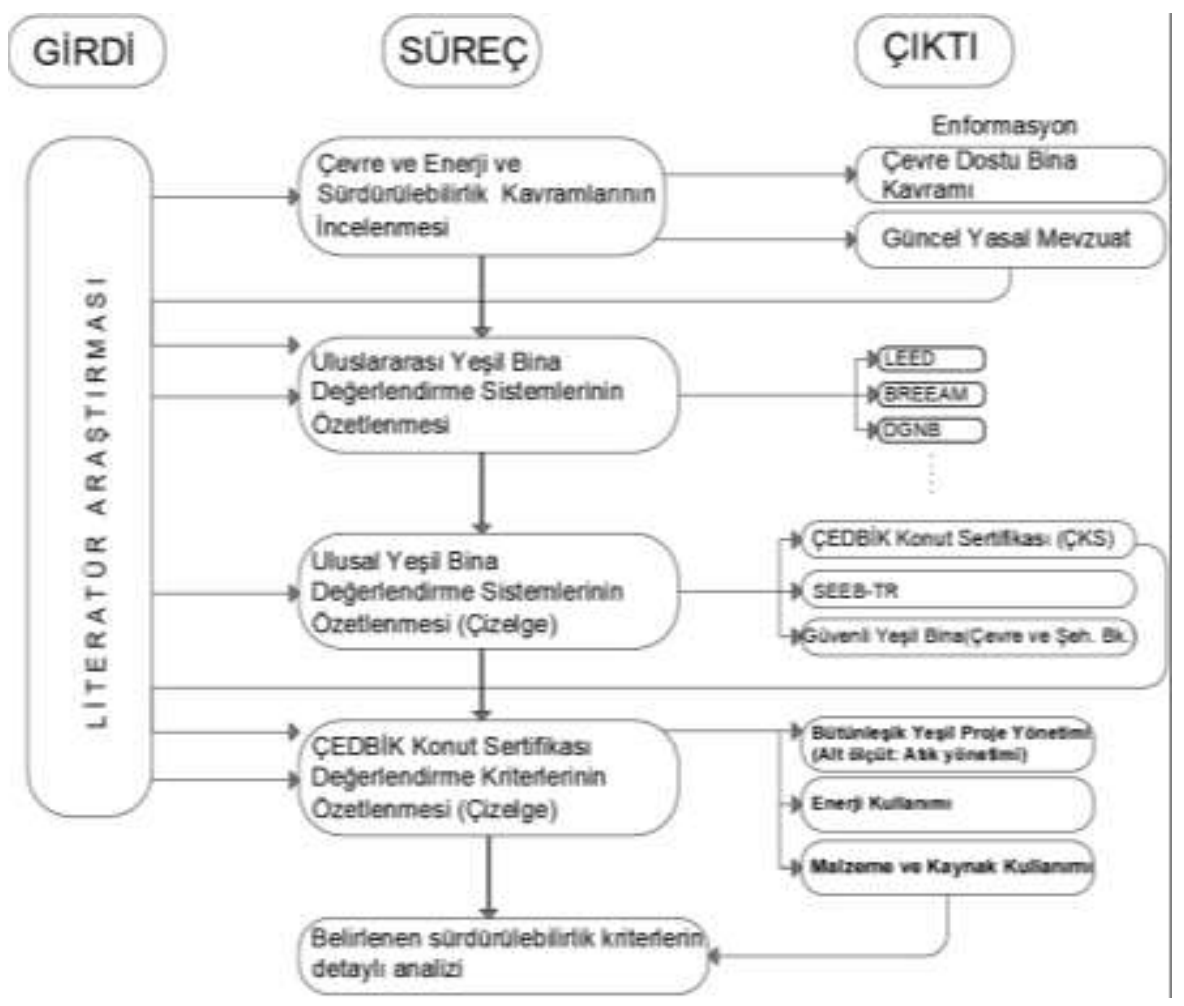

Şekil 1. Çalışmanın süreç modeli - 1. Bölüm (Diker, 2016).

\section{Çevre, Enerji ve Sürdürülebilirlik Kavramları}

Çevre, enerji ve sürdürülebilirlik birbiri ile ilişkili kavramlardır. Ünlü (1991) çevreyi; insanoğlunun ihtiyaçlarını karşılamak, neslini devam ettirmek için, sürekli üretim ve tüketim faaliyetlerinde bulunduğu, dinlendiği doğal, kültürel ve yapay ortam olarak tanımlamaktadır (Ünlü, 1991). 
Enerji ise, "Bir sistemin iş yapma yeteneğini veya gücünü niteleyen bir kavramdır" (Çepel, 1995). Enerjinin çevreyle olan negatif etkileşimi özellikle sanayileşme sonrası daha belirgin bir şekilde görülmektedir. 18. yüzyılın ikinci yarısında gerçekleşen endüstri devrimi, ardından başlayan ve hızla gelişen sanayileşme olgusu zaman içinde insan - doğa dengesinin bozulmasına sebep olan çevre kirliliğinin başlangıç noktasını oluşturmaktadır (Alkin \& İlkin, 1991).

1970'lerde yaşanan enerji krizi ile birlikte çevre sorunlarına yönelik incelemeler artmış ve bu durum uluslararası platformlara taşınarak pek çok kez görüşülmüştür. İlk anlamıla "kesinti ya da azalma olmadan varlığını devam ettirebilme kapasitesi" anlamına gelen sürdürülebilirlik kavramının tarihsel kökeni her ne kadar Antik Roma dönemine dayanmakta olsa da (Worldwatch Enstitüsü, 2014); çevre sorunları ile birlikte ilk kez 'Ortak Geleceğimiz' adlı raporda ele alınmıştır. Bu rapora göre; "sürdürülebilir kalkınma, gelecek nesillerin ihtiyaçlarını karşılama olanakların ellerinden almadan; şimdiki neslin ihtiyaçlarının karşılanabildiği gelişme sürecidir" (World Commission on Environment, 1987).

Türkiye'de ise diğer dünya ülkelerinde olduğu gibi 1950'li yıllardan itibaren sanayileşmenin etkisi ile enerji tüketimi ivme kazanmıştır. Kentlerde artan nüfus, kontrolsüz bina üretimini tetiklemiş; buna bağlı olarak da enerji ve kaynak tüketimi artmıştır. Çevreye olan baskının önlenmesi için, enerji/kaynak verimliliği ve yönetimi konularında yasal çerçeve oluşturulmuştur. İlk olarak, 1983 yılında 2872 sayılı Çevre Kanunu yayınlanmış ve ilk olarak bu kanunda "çevre kirliliği", "ekolojik denge", "atık" gibi kavramların tanımları yapılmıştır. 2005 yılında 5346 sayılı kanun ile yenilebilir enerji kaynaklarının kullanılarak elektrik enerjisi üretilmesi ve sera gazı emisyonlarının azaltılmasına yönelik bir yol haritası çizilmiştir. 2007 yılında yayınlanan 5627 sayılı Enerji Verimliliği Kanunu ise, enerjinin etkin kullanımı ve kaynak israfının azaltılmasına yönelik bir adımları içermektedir. 2008 yılında yayınlanan 27075 sayılı yönetmelik ile binaların enerji performansını iyileştirmeye yönelik birtakım hedefler getirilmiştir; bu yıldan itibaren yapılara Enerji Kimlik Belgesi verilmesi zorunlu hale getirilmiştir.

1983 yılından günümüze kadar olan süreçte, Türkiye' de çevre ve enerji korunumuna yönelik oluşturulan yasal mevzuat Tablo 1'de verilmiştir: 
Tablo 1. Çevre ve enerji ile ilgili yasal mevzuatın bir bölümü.

\begin{tabular}{lll}
\hline Tarih & Sayı & Kanun/Yönetmelik \\
\hline $09 / 08 / 1983$ & 2872 & Çevre Kanunu \\
\hline $10 / 05 / 2005$ & 5346 & $\begin{array}{l}\text { Yenilenebilir Enerji Kaynaklarının Elektrik Enerjisi } \\
\text { Üretimi Amaçlı Kullanımına Illişkin Kanun }\end{array}$ \\
\hline $18 / 04 / 2007$ & 5627 & Enerji Verimliliği Kanunu \\
\hline $05 / 07 / 2008$ & 26927 & Atık Yönetimi Genel Esaslarına İlişkin Yönetmelik \\
\hline $21 / 11 / 2008$ & 27061 & Çevre Denetimi Yönetmeliği \\
\hline $05 / 12 / 2008$ & 27075 & Binalarda Enerji Performansı Yönetmeliği \\
\hline $03 / 10 / 2013$ & 28784 & Çevresel Etki Değerlendirmesi Yönetmeliği \\
\hline $08 / 12 / 2014$ & & $\begin{array}{l}\text { Sürdürülebilir Yeşil Binalar ile Sürdürülebilir Yerleş- } \\
\text { melerin Belgelendirilmesine Dair Yönetmelik (Yü- } \\
\text { rürlükten kaldırıldı) }\end{array}$ \\
\hline $02 / 04 / 2015$ & 29314 & Atık Yönetimi Yönetmeliği \\
\hline $23 / 03 / 2017$ & 30016 & $\begin{array}{l}\text { Atık Yönetimi Yönetmeliğinde Değişiklik } \\
\text { Yapılmasına Dair Yönetmelik }\end{array}$ \\
\hline $06 / 07 / 2018$ & 30470 & Binalar ile Yerleşmeler için Yeşil Sertifika Yönetme- \\
& & liği \\
\hline
\end{tabular}

\section{Binalarda Enerji Verimliliği}

Enerji tüketiminin sektörlere göre dağılımına bakıldığında, binalar tüketimin büyük bir bölümünden sorumludur (Karabalık \& Özyurt, 2009). Worldwatch Enstitüsü'nde kıdemli araştırmacı olarak görev alan Michael Renner şöyle belirtmektedir; "Binalar enerji, su ve materyallerin en büyük kullanıcıları arasinda ve sera gazı salımlarna da önemli oranda katkıda bulunuyorlar. Özellikle küresel bina stoku hızla arttığı için, bina inşaatı ve yönetimini sürdürülebilirlik hedefleri ile uyumlu hale getirmek için çok geniş ölçekte politika gerekiyor" (Renner, 2016).

Türkiye' de 2011 yılı itibariyle mevcut stokun yaklaşık yüzde seksenini konut binaları oluşturmaktadır (Bayraktar, 2007). Bu stokun büyük bir bölümü, yalıtımsız ve niteliksiz binalardan oluşmaktadır. Bu yapı stokunun iyileştirilmesi veya yenilenmesi sürecinde, 2023 yılına kadar Türkiye'de yaklaşık 7 milyon 560 bin konuta ihtiyaç duyulacaktır (Gürlesel, 2012). Bu kapsamda, yeni yapılacak konut binalarının enerji performansını iyileştirecek düzenlemeler ile önemli oranda enerji tasarrufu sağlanabilir. 
Binalarda enerji performansının iyileştirilmesine yönelik yapılan çalışmalardan biri de 'yeşil bina değerlendirme sistemleri' dir. Günümüzde, birçok dünya ülkesi kendi yerel koşullarına göre oluşturduğu sistemler arac1lığıyla binaların enerji performans değerlendirmesini yapabilmektedir. Bu değerlendirme sistemlerinden en çok bilinenleri İngiltere'de 1990 y1lında ortaya çıkan ve halen kullanımda olan BREEAM ile 1998 yılında Amerika'da kullanılmaya başlanan LEED sertifika sistemleridir. Bunlara ek olarak; çeşitli dünya ülkelerinde kullanılan yeşil bina değerlendirme sistemlerinden yaygın olarak kullanımda olanları; geliştirildikleri yıl, kullanıldıkları ülkeler ve geliştirici kurumları bağlamında Tablo 2' de özetlenmiştir:

Tablo 2. Dünya'daki yeşil bina değerlendirme sistemlerinden bazıları (Renner, 2016).

\begin{tabular}{|c|c|c|c|}
\hline 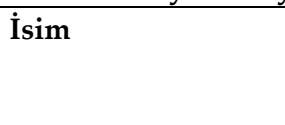 & $\begin{array}{l}\text { Geliştirildiği } \\
\text { veya Kabul } \\
\text { Edildiği Yıl }\end{array}$ & Kullanılan Ülkeler & $\begin{array}{l}\text { Geliştiren/ Uygulayan } \\
\text { Kurum }\end{array}$ \\
\hline $\begin{array}{l}\text { BREEAM (Building } \\
\text { Research Establish- } \\
\text { ment Environmen- } \\
\text { tal Assessment } \\
\text { Methodology) }\end{array}$ & 1990 & $\begin{array}{l}\text { Birleşik Krallık, Av- } \\
\text { rupa, Basra Körfezi } \\
\text { ülkeleri ve diğerleri }\end{array}$ & $\begin{array}{l}\text { Building Research Es- } \\
\text { tablishment Global }\end{array}$ \\
\hline $\begin{array}{l}\text { LEED (Leadership } \\
\text { in Energy and En- } \\
\text { vironmental De- } \\
\text { sign }\end{array}$ & 1998 & $\begin{array}{l}\text { ABD, 150'den fazla } \\
\text { ülke }\end{array}$ & $\begin{array}{l}\text { U.S. Green Building } \\
\text { Council }\end{array}$ \\
\hline $\begin{array}{l}\text { Green Globes } \\
\text { (Kanada'da BOMA } \\
\text { BEST (Building En- } \\
\text { vironmental Stand- } \\
\text { ards) olarak yeni- } \\
\text { den adlandırılmış }\end{array}$ & 2000 & $\begin{array}{l}\text { Kanada, } 2004 \text { yılında } \\
\text { ABD için Yeşil Bina } \\
\text { İnisiyatifi tarafından } \\
\text { kabul edildi. }\end{array}$ & $\begin{array}{l}\text { ECD Energy and Envi- } \\
\text { ronment Kanada } \\
\text { (BOMA- Building } \\
\text { Owners\& Management } \\
\text { Association tarafindan } \\
\text { uygulaniyor. }\end{array}$ \\
\hline $\begin{array}{l}\text { CASBEE (Compre- } \\
\text { hensive Assess- } \\
\text { ment System for } \\
\text { Building Environ- } \\
\text { mental Efficiency) }\end{array}$ & 2001 & Japonya & $\begin{array}{l}\text { Japan Sustainable } \\
\text { Building Consortium }\end{array}$ \\
\hline Green Star & 2003 & $\begin{array}{l}\text { Avusturalya, Yeni } \\
\text { Zelanda }\end{array}$ & $\begin{array}{l}\text { Green Building Coun- } \\
\text { cil of Australia }\end{array}$ \\
\hline Green Mark & 2005 & Singapur & $\begin{array}{l}\text { Building and Construc- } \\
\text { tion Authority }\end{array}$ \\
\hline Sustainable SITES & 2006 & $\mathrm{ABD}$ & $\begin{array}{l}\text { Green Business Certifi- } \\
\text { cation, Inc. }\end{array}$ \\
\hline
\end{tabular}




\begin{tabular}{|c|c|c|c|}
\hline $\begin{array}{l}\text { Living Building } \\
\text { Challenge }\end{array}$ & 2006 & $\begin{array}{l}\text { Cascadia (ABD ve } \\
\text { Kanada) }\end{array}$ & $\begin{array}{l}\text { International Living } \\
\text { Future Institute }\end{array}$ \\
\hline $\begin{array}{l}\text { GBEL (Green } \\
\text { Building Evalua- } \\
\text { tion Label) }\end{array}$ & 2006 & Çin & $\begin{array}{l}\text { China Building Science } \\
\text { Research Institute tara- } \\
\text { fından geliştirildi; yer- } \\
\text { leşim ve Kentsel -Kır- } \\
\text { sal Kalkınma Bakanlığ1 } \\
\text { tarafından uygulanı- } \\
\text { yor. }\end{array}$ \\
\hline $\begin{array}{l}\text { GRIHA (Green } \\
\text { Rating for Inte- } \\
\text { grated Habitat As- } \\
\text { sessment) }\end{array}$ & 2007 & Hindistan & $\begin{array}{l}\text { The Energy and Re- } \\
\text { sources Institute } \\
\text { (TERI) }\end{array}$ \\
\hline $\begin{array}{l}\text { AQUA (Alta Quali- } \\
\text { dade Ambiental) }\end{array}$ & 2008 & Brezilya & $\begin{array}{l}\text { Fundaçao Vanzolini } \\
\text { Fransız HQE (Haute } \\
\text { Qualite Environne- } \\
\text { mentale) standardını } \\
\text { Brezilya koşullarına } \\
\text { uyguladı }\end{array}$ \\
\hline $\begin{array}{l}\text { Pearl Rating Sys- } \\
\text { tem for Estidama }\end{array}$ & 2008 & $\begin{array}{l}\text { Birleşik Arap Emir- } \\
\text { likleri }\end{array}$ & $\begin{array}{l}\text { Abu Dabi Urban Plan- } \\
\text { ning Council }\end{array}$ \\
\hline $\begin{array}{l}\text { Green Star South } \\
\text { Africa }\end{array}$ & 2008 & Güney Afrika & $\begin{array}{l}\text { Green Building Coun- } \\
\text { cil of South Africa } \\
\text { (Avusturalya sistemin- } \\
\text { den alındı) }\end{array}$ \\
\hline LOTUS & 2008 & Vietnam & $\begin{array}{l}\text { Vietnam Green Build- } \\
\text { ing Council }\end{array}$ \\
\hline $\begin{array}{l}\text { Building Environ- } \\
\text { mental Assessment } \\
\text { Method (BEAM) }\end{array}$ & 2009 & Hong Kong & $\begin{array}{l}\text { Hong Kong Green } \\
\text { Building Council }\end{array}$ \\
\hline
\end{tabular}

Son yıllarda LEED ve BREEAM sertifikalarının Türkiye'de yaygın olarak kullanımı görülse de kendi ülke koşullarına uygun olarak hazırlanmış olan bu sistemlerin Türkiye özelindeki problemleri çözmede yetersiz kaldığı konusu gündeme gelmiş ve daha önce yapılan çalışmalarda da 'yerel sistem gerekliliği' vurgulanmıştır (Aydın, 2013).

Bununla ilgili olarak, yakın geçmişte bina enerji performansını değerlendirmede kullanılacak ulusal sertifikanın geliştirilmesine yönelik adımlar atılmıștır. Bunlardan en bilinenleri; Türk Standartları Enstitüsü'nün 2014 yılında hazırlamış olduğu 'TSE Güvenli Yeşil Bina', Mimar Sinan Güzel Sanatlar Üniversitesi'nin 2013 yılı itibari ile tanıttı̆ 'SEEB-TR' kılavuzu ve Çevre Dostu Binalar Derneği'nin (ÇEDBİK) 2015 yılında hazırladığı 'Ulusal Konut Sertifika 
Kılavuzu'dur. Bu üç sistemin ele aldığı değerlendirme kriterleri karşılaştırmalı olarak Tablo 3 'te verilmiştir.

Tablo 3. Türkiye' deki yeşil bina değerlendirme sistemlerinden bazıları ve değerlendirme kriterleri (Diker, 2016).

\begin{tabular}{|c|c|c|}
\hline $\begin{array}{l}\text { TSE Güvenli Yeşil Bina } \\
\text { (2014) }\end{array}$ & SEEB -TR (2013) & $\begin{array}{l}\text { ÇEDBİK Konut Sertifika } \\
\text { Kılavuzu (Haziran, 2015) }\end{array}$ \\
\hline \multicolumn{3}{|l|}{$\begin{array}{c}\text { Güvenli Yeşil Bina Başlangıç } \\
\text { Tasarımı }\end{array}$} \\
\hline Yaşamsal Alan Tasarımı & Tasarım & Konutta Yaşam \\
\hline Alan Seçimi & Arazi Kullanımı & Arazi Kullanımı \\
\hline Sağlık, Güvenlik ve Konfor & Konfor & Sağlık ve Konfor \\
\hline Suyun Etkin Kullanımı & Su Verimliliği & Su Kullanımı \\
\hline $\begin{array}{c}\text { Malzeme ve Kaynak Kulla- } \\
\text { nımı }\end{array}$ & $\begin{array}{c}\text { Malzeme ve Kaynak Kulla- } \\
\text { nimı }\end{array}$ & $\begin{array}{c}\text { Malzeme ve Kaynak Kulla- } \\
\text { nimı (6) }\end{array}$ \\
\hline \multicolumn{3}{|l|}{ Karbon ayak izi } \\
\hline Enerji Verimliliği & Enerji & Enerji Kullanımı (4) \\
\hline İşletme Yönetimi & İşletme ve Bakım & İşletme ve Bakım \\
\hline Ödül Puanı & Proje ve Yapım Yönetimi & Yeşil Proje Yönetimi (1) \\
\hline \multicolumn{3}{|c|}{ Atık Yönetimi } \\
\hline \multicolumn{3}{|c|}{ Kirlilik } \\
\hline \multicolumn{3}{|c|}{ Uyarlanabilirlik } \\
\hline \multicolumn{3}{|c|}{ Yangın Güvenliği ve Afet } \\
\hline
\end{tabular}

Bu çalışmada, ÇEDBİK Konut sertifikası 'değerlendirme aracı' olarak ele alınmış ve sertifikadaki kriterler üzerinden çalışma yürütülmüştür.

ÇEDBIK Konut Sertifikası (ÇKS), Amerikan yeşil bina değerlendirme sistemi olan LEED (Leadership in Energy and Environmental Design), İngiltere'nin yeşil bina değerlendirme sistemi BREEAM (Building Research Establishment's. Environmental Method) ve Alman yeşil bina değerlendirme sistemi DGNB (Deutsche Gesellschaft für Nachhaltiges Bauen e.V.) baz alınarak, Türkiye'nin yerel koşullarına göre yeniden düzenlenmiştir. İlk olarak 2013 yılının Eylül ayında beta versiyonu olarak çıkarılan kılavuz, daha sonra 2015 ve 2016 yılının Haziran ayında revize edilerek tekrar yayımlanmıştır (Diker, 2016). Güncel olarak sertifikanın 20181.0 versiyonu bulunmaktadır.

ÇKS, toplamda 9 ana başlıktan oluşmaktadır. Bunlar: Bütünleşik Yeşil Proje Yönetimi (1), Arazi Kullanımı (2), Su Kullanımı (3), Enerji Kullanımı (4), 
Sağllk ve Konfor (5), Malzeme ve Kaynak Kullanımı (6), Konutta Yaşam (7), İşletme ve Bakım (8) ve Yenilikçilik (9)'tir (Çevre Dostu Binalar Derneği, 2018). Çalışma kapsamında ele alınacak olan 1, 4 ve 6 numaralı değerlendirme ölçütleri ile kapsam ve gereklilikleri sağlandığı takdirde tasarım ve inşaat aşamasında sertifikada kazanılacak puanlar Tablo 4'te gösterilmiştir:

Tablo 4. ÇKS Değerlendirme ölçütlerinin puanlaması (Çevre Dostu Binalar Derneği, 2018).

Değerlendirme Kriterleri

Alınabilecek Tasarım İnşaat Toplam puan

\begin{tabular}{lllc}
\hline Bütünleşik yeşil proje yönetimi (1) & & & \\
\hline Önkoşul entegre tasarım & Önkoşul & & Önkoşul \\
\hline Entegre tasarım & $1-2$ & 2 & - \\
\hline Çevreye duyarlı müteahhit & 2 & 1 & 1 \\
\hline İnşaat atık yönetimi (3) & 3 & 2 & 1 \\
\hline Gürültü kirliliği & 2 & 1 & 1 \\
\hline
\end{tabular}

Enerji kullanımı (4)

\begin{tabular}{|c|c|c|c|c|}
\hline Kontrol, İşletmeye alma ve Kabul & Önkoşul & & ş̧ul & \multirow{7}{*}{26} \\
\hline Enerji verimliliği & Önkoşul & & şul & \\
\hline Enerji Verimliliği & $1-15$ & 15 & - & \\
\hline Yenilenebilir enerji kullanımı & $1-7$ & 2 & 5 & \\
\hline Dış aydınlatma & 1 & 1 & - & \\
\hline Enerji verimli beyaz eşyalar & 1 & - & 1 & \\
\hline Asansörler & 2 & 1 & 1 & \\
\hline \multicolumn{5}{|l|}{ Malzeme ve kaynak kullanımı (6) } \\
\hline Çevre dostu malzeme & 3 & - & 3 & \multirow{5}{*}{15} \\
\hline $\begin{array}{l}\text { Mevcut bina elemanlarından yarar- } \\
\text { lanılmasi }\end{array}$ & $1-3$ & - & 3 & \\
\hline Malzemenin yeniden kullanımı & $1-3$ & - & 3 & \\
\hline Yerel malzeme kullanımı & $2-4$ & - & 4 & \\
\hline Dayanıklı malzeme & $1-2$ & - & 2 & \\
\hline
\end{tabular}

* Çalışma kapsamında incelenen ölçütler.

Yapılan değerlendirmeye ışık tutmak adına, seçilen ölçütlerin kapsam ve gereklilikleri bu bölümde tartışılmıştır.

Bütünleşik Yeşil Proje Yönetimi (1) ölçütünün amac1, sürdürülebilir tasarım ve inşaat konusunda uzmanların bir araya gelerek yeşil konut projesini bütünleşik bir yaklaşımla yönetmelerini sağlamaktır (Çevre Dostu Binalar Derneği, 2018). Bu değerlendirme ölçütünün kapsadığı alt ölçütler; Entegre Tasarım (1), Çevreye Duyarlı Müteahhit (2), İnşaat Atık Yönetimi (3) ile Gürültü Kirliliği (4)'dir. Çalışma kapsamında İnşaat Atık Yönetimi isimli alt ölçüt ele alınmıştır. 
İnşaat atık yönetimi (3), inşaat sürecinde oluşan moloz ve atıkların yönetimini kapsamaktadır. Hedef, yapım esnasında oluşan hafriyat, beton, tuğla, asfalt, karışık moloz, alçı vb. inşaat atığı, ambalaj atığı, ahşap ve mobilya, cam, plastik, metal gibi atıkların geri dönüşüm ya da bertaraf yöntemini belirlemektedir (Çevre Dostu Binalar Derneği, 2018). Ölçüt kapsamında yapım sürecine yönelik detaylı bir atık yönetim planı hazırlanması ve atıkların sahada yeniden kullanımı, kullanılamayacak durumda olan atıkların ise lisanslı geri dönüşüm firmaları aracılığıyla geri dönüşüm sürecine aktarılması önerilmektedir.

Enerji Kullanımı (4) başlıklı değerlendirme ölçütü, enerji verimli binaların üretimini arttırmayı amaçlamaktadır. Yenilenebilir enerji kaynaklarının kullanımını yaygınlaştırmak ve binaların doğal çevre ile olan ilişkisini iyileştirmek ölçütün alt hedeflerindendir. Enerji kullanımı; Kontrol, İşletmeye Alma ve Kabul (1), Enerji verimliliği (2), yenilenebilir enerji kullanımı (3), dış aydınlatma (4), enerji verimli beyaz eşyalar (5) ve asansörler (6) alt ölçütlerinden oluşmaktadır. Çalışma kapsamında 2, 3 ve 5 numaralı alt ölçütler ele alınmıştır.

Enerji verimliliği (2) isimli alt ölçüt binaların enerji tüketimi ve karbon salımlarının azaltılmasını hedeflemektedir. Yenilenebilir enerji kullanımı (3) isimli ölçüt, sera gazı emisyonlarının ve fosil kaynaklı yakıt kullanımının azaltılmasını amaçlamaktadır. Bunun için, inşaat sahası içinde veya dışında yenilenebilir enerji teknolojilerinin kullanılmasını öngörmektedir. Enerji verimli beyaz eşyalar (5) isimli ölçüt ise, yatırımcının konut içerisinde planladığı/satın alacağı cihazların A veya daha üst bir enerji sınıfında seçilmesini zorunlu tutmaktadır (Çevre Dostu Binalar Derneği, 2018).

Malzeme ve kaynak kullanımı (6) başlıklı değerlendirme ölçütünün amacı, konut sektörünü çevreye duyarlı ve yerel malzemeye teşvik etmektir. ÇKS, binada kullanılacak malzemelerin çevre dostu, geri dönüştürülebilir, dayanıklı ve yerel malzeme olmasını öngörmektedir (Çevre Dostu Binalar Derneği, 2018). Bu değerlendirme ölçütü altında; çevre dostu malzeme (1), mevcut bina elemanlarından yararlanılması (2), malzemenin yeniden kullanımı (3), yerel malzeme kullanımı (4) ve dayanıkl malzeme (5) alt ölçütleri bulunmaktadır. Çalışmada tüm alt ölçütler ele alınmıştır.

Çeore dostu malzeme (1) isimli alt ölçüt, adından da anlaşılacağı üzere, çevreye duyarlı malzeme kullanımını teşvik etmeyi amaçlamaktadır. Bu ölçüt kapsamında, yapı elemanlarını oluşturan malzemelerin, EU ECO LABEL (eko-etiket), EPD (çevresel ürün beyanı), CE, FSC gibi çevre etiketlerine sahip olmaları istenmektedir (Çevre Dostu Binalar Derneği, 2018). Mevcut bina ele- 
manlarından yararlanılması (2) alt ölçütü, kaynak kullanımının ve inşaat atı̆̆1nın azaltılmasına yönelik mevcut bina elemanlarından yararlanmayı teşvik etmektedir. Söz konusu bina elemanları taşıyıcı sistem elemanları olabileceği gibi, bina cephe elemanı da olabilmektedir. Malzemenin yeniden kullanımı (3) alt ölçütü, geri dönüştürülebilen ya da çabuk yenilenebilen malzemelerin yapıda kullanımını teşvik etmektedir. Yerel malzeme kullanımı (4), inşaat sürecinin nakliye aşamasındaki karbon salım miktarını azaltmak için, yapının inşa edildiği bölgede üretilen malzemelerin yapıda kullanımını teşvik etmeyi amaçlamaktadır. Ölçütte, malzemenin taşıma yolunun uzaklığına göre puanlama yapılmaktadır. Son olarak, dayanıklı malzeme (5) alt ölçütü, yapı kabuğunda ve yapı içerisinde kullanılan malzemelerin yıpranmaya karşı dayanıklı olmasını desteklemektedir. Değerlendirme ölçütünün, malzemelerin servis ömürleri ve garanti süreleri hakkında koşulları vardır.

\section{Yöntem}

Bu çalışmada, Fikirtepe'de planlanan yeni konut binaları üzerinden çevresel sürdürülebilirliğe dair mevcut durum değerlendirmesi yapılması hedeflenmiştir. Çalışmanın yapıldığı 2015-2017 yılları arasında, bölgede ruhsat almış ve yapım süreci başlamış olan 17 (on-yedi) konut binası (rezidans) üzerinden 10 (on) tanesi çalışma kapsamında incelenmek üzere seçilmiştir. Binaların çevresel açıdan performanslarının ölçülebilmesi için ÇEDBİK Konut Sertifikası bir 'değerlendirme aracı' olarak kullanılmıştır. Seçilen değerlendirme ölçütlerinin her biri için; konunun kapsam ve gerekliliğinin sağlanıp sağlanmadığını ölçen anket soruları oluşturulmuştur (Ek-2 ve Ek-3). Daha sonra, anket aracilığı ile alınması planlanan verilerin kimlerden ve hangi yöntem ile elde edilebileceğine yönelik bir çalışma modeli oluşturulmuştur. Çalışma modeli Şekil 2'de verilmiştir.

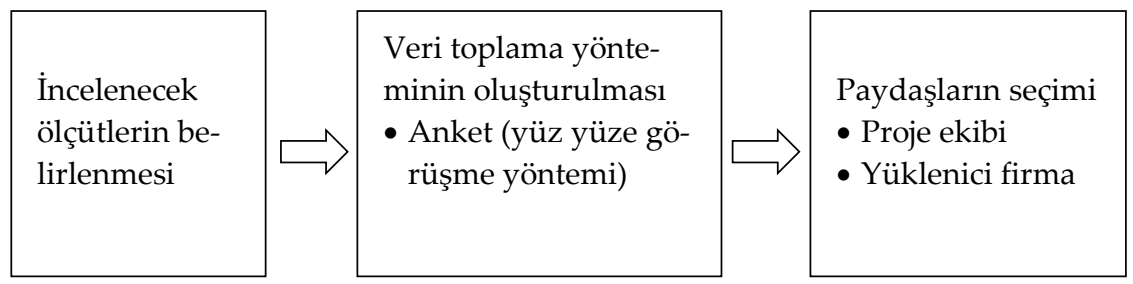

Şekil 2. Çalışma modeli. (Diker, 2016). 
Paydaşların iki gruba indirgenmesinden sonra, anket formları proje ekibi ve yüklenici firmaya yöneltilmek üzere ayrılmıştır. Daha sonra, seçilen 10 konut binasının her biri için, tasarım sürecini yürüten proje ekipleri ve yapım sürecini yürüten yüklenici firmalar ile 2016 yılının yüz yüze görüşmeler yapılmış ve hazırlanan anket üzerinden cevaplar alınmıştır (Diker, 2016).

Elde edilen veriler doğrultusunda, pilot bölge Fikirtepe'deki yeni konut binalarının, enerji ve kaynak kullanımı ile atık yönetimi konularındaki farkındalık durumu incelenmiştir. Verilen cevaplara göre, sertifikada tanımlanan koşulların sağlanıp sağlanamadığına ilişkin ölçüt bazında uygunluk kontrolleri yapılmış ve elde edilen bulgular çizelge ve grafiklerle desteklenmiştir. Çalışmanın bu bölümünü kapsayan süreç modeli Şekil 3'te verilmiştir:

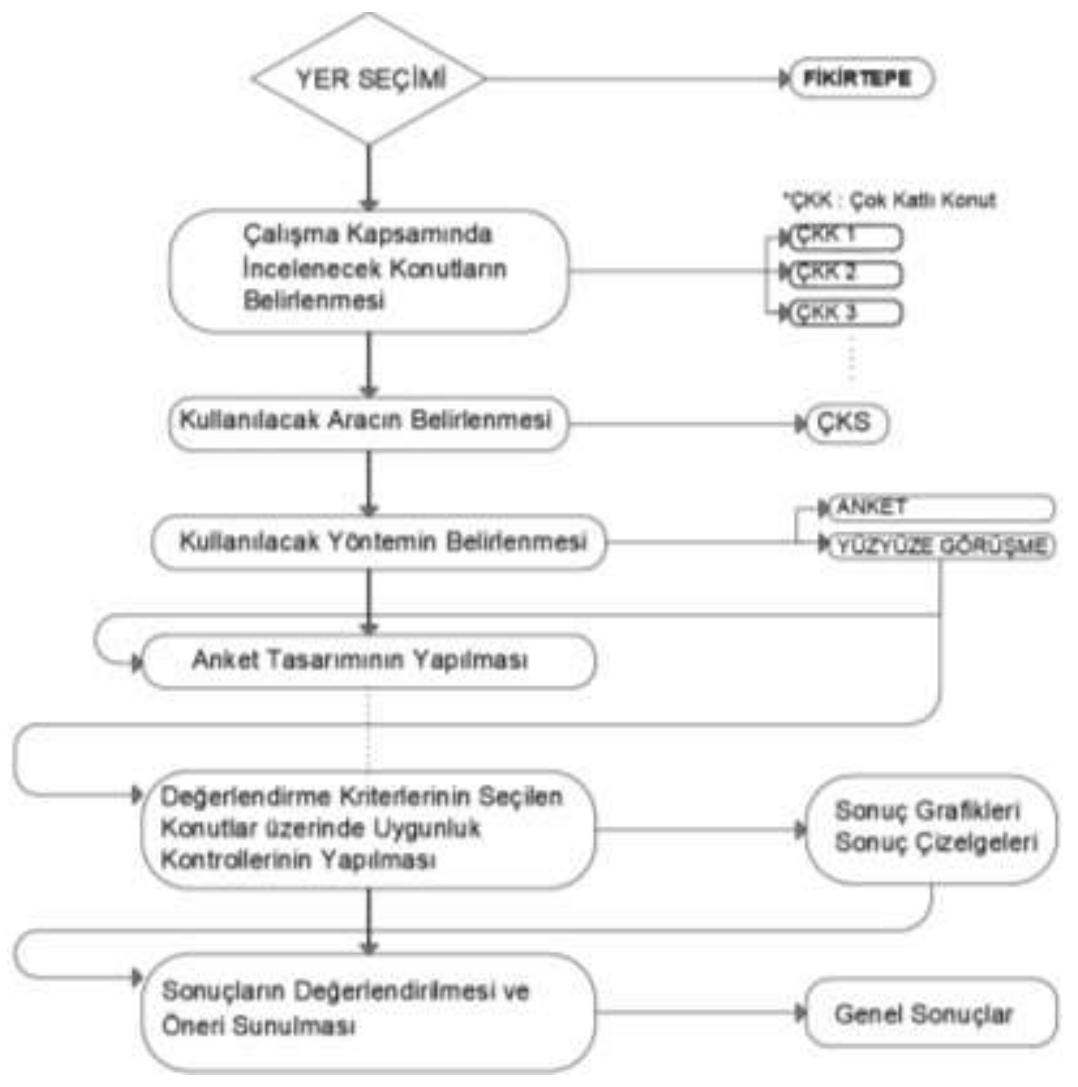

Şekil 3. Çalışmanın Süreç Modeli - 2. Bölüm (Diker, 2016).

Bir sonraki bölümde, çalışma alanı olarak belirlenen Fikirtepe'nin tarihsel süreç içerisindeki dönüşümü kısaca aktarıldıktan sonra, bu bölümde tanımlanmış olan yöntem, seçilen alan üzerinde adım adım uygulanmıştır. 


\section{Alan Çalışması: Fikirtepe Kentsel Dönüşüum Alanı}

Fikirtepe, İstanbul Anadolu Yakası'ndaki Kadıköy ilçe sınırları içerisindedir. Kadıköy ilçesi geniş yüzölçümü, nüfus büyüklüğü, kozmopolitan yaşamı, 8 km'yi aşan sahili, kent içindeki semtleri birbirine bağlayan ana ulaşım yolları, sosyal, kültürel, ekonomik ve toplumsal faaliyetler açısından zenginliğiyle İstanbul'un en önemli ilçelerindendir (Fikirtepe Kentsel Tasarım Çerçevesi, 2013).

Fikirtepe, 1950'li yıllardan itibaren sanayi devrimine paralel olarak yoğun göç alarak kentleşme sürecine girmiştir. Ne yazık ki, bu süreç plansız bir şekilde gerçekleştiğinden, bölgenin büyük bir kısmı çarpık yapılaşmaya maruz kalarak gecekondu alanına dönüşmüştür. Aşırı nüfus ve niteliksiz yapılaşma, sağlıksız yaşam koşullarını beraberinde getirmiş, bölgeyi bir "çöküntü alanına" çevirmiş̧ir (Diker, 2016).

2014 yllından günümüze kadar olan süreçte bölgenin fiziksel değişimini gösteren fotoğraflar Şekil 4'te verilmiştir:
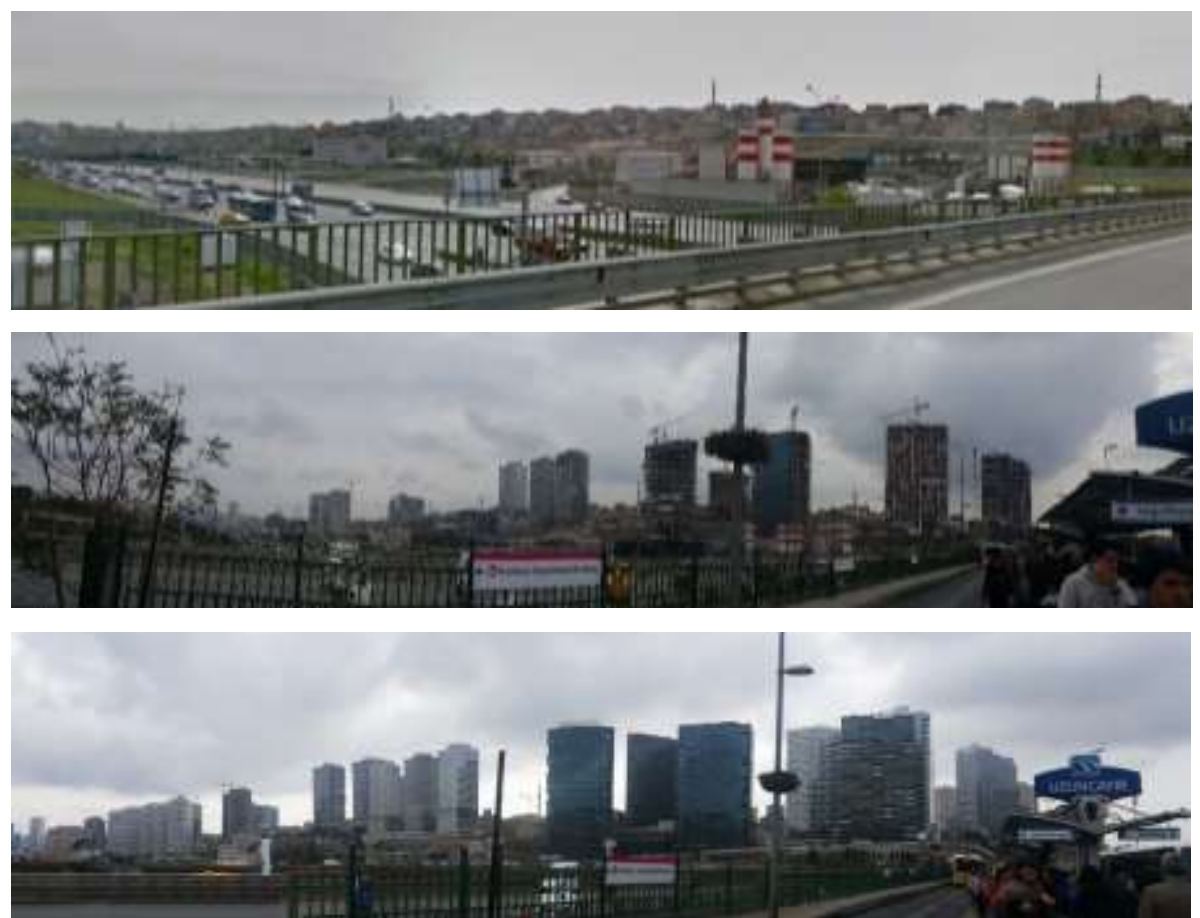

Şekil 4. Fikirtepe'nin Mart 2014 tarihli Google sokak görüntüsü 2. fotoğraf: 23 Ekim 2016 tarihli Fikirtepe fotoğrafı. 3. fotoğraf: 18 Ekim 2018 tarihli Fikirtepe fotoğrafı. 
Fikirtepe'deki kentsel dönüşüm süreci, 2013 yılında Çevre ve Şehircilik Bakanlığı'nın Kadıköy ilçesi Fikirtepe ve Dumlupınar Mahalleleri ile Eğitim ve Merdivenköy Mahallelerinin bir kısmını kapsayan 134 hektarlık bir alanı 6306 sayılı "Afet Riski Altındaki Alanların Dönüştürülmesi Hakkındaki Kanun" uyarınca "Riskli Alan" ilan etmesi ile gündeme gelmiştir. Yine aynı yıl içerisinde "1/1000 ölçekli Fikirtepe ve Çevresi Uygulama İmar Planı" çalışmaları hız kazanmıştır. 1984 yılında çıan 2981 sayılı yasa ve öncesinde yaşanan süreç, Fikirtepe'yi parsel bazında bölmüş ve günümüz kent dokusunu oluşturmuştur (Şekil 5).

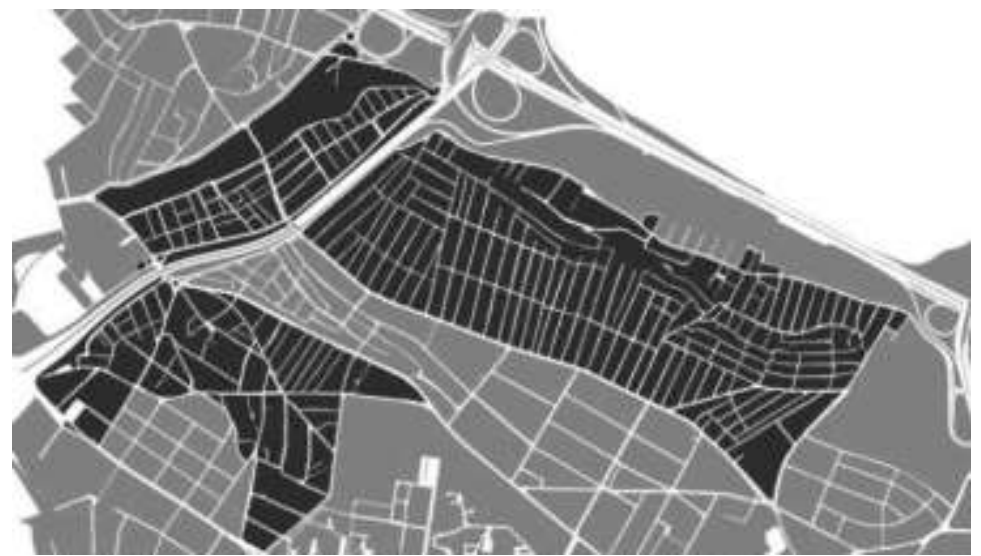

Şekil 5. Fikirtepe'deki eski ızgara plan (Fikirtepe Kentsel Tasarım Çerçevesi, 2013).

Yeni yasal süreç ise Fikirtepe'nin bölünmüş parsellerini tekrar birleştirmeyi amaçlamaktadır. Bu birleştirmeler sonucunda; 62 adet yapılaşmaya hazır ada oluşturulmuştur (Şentürk, 2014). Planlama sonucu oluşan adalar Şekil 6'da gösterilmiştir.

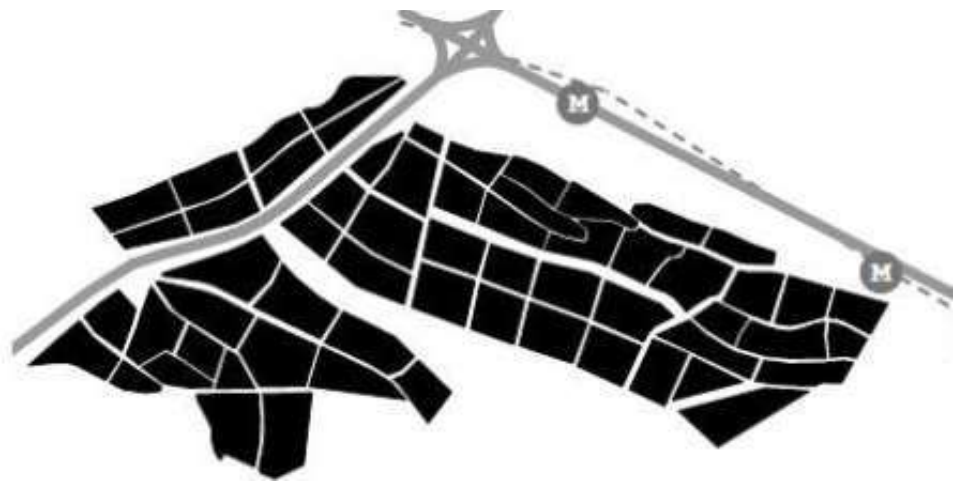

Şekil 6. Fikirtepe' de kentsel dönüşüm sonrası oluşacak plan- 62 adet yapı adası- (Fikirtepe Kentsel Tasarım Çerçevesi, 2013). 
1/1000 Ölçekli Fikirtepe ve Çevresi Uygulama İmar Plan Raporu'na göre; yapı adalarının büyüklüğü arttıkça ilave emsal hakkı kazanılmaktadır (Çevre ve Şehircilik Bakanlığı, 2013). Bu durum, yapı adalarının devalasalaşarak her birinin birer kapalı yerleşmeye dönüşme riskini tetiklemektedir (Diker, 2016).

2013 yılında dönüşümdeki aktörlerin bir araya gelmesi ile hazırlanan Fikirtepe Kentsel Tasarım Çerçevesi, özünde bir master plan taslağı olarak düşünülse de çevre ve ekoloji bağlamında eksiklikler içermektedir. Bu nedenle, bölge bazında çözüm önerisi geliştirilmelidir.

Ekim 2018 itibari ile Fikirtepe bölgesinde;

- 10 adet projenin yapım süreci tamamlanmış (kırmıı ile gösterilmiş)

- 27 adet proje henüz başlamamış (pembe ile gösterilmiş),

- 18 adet projenin ise yapım süreci devam etmektedir (mavi ile gösterilmiş) (Şekil 7).

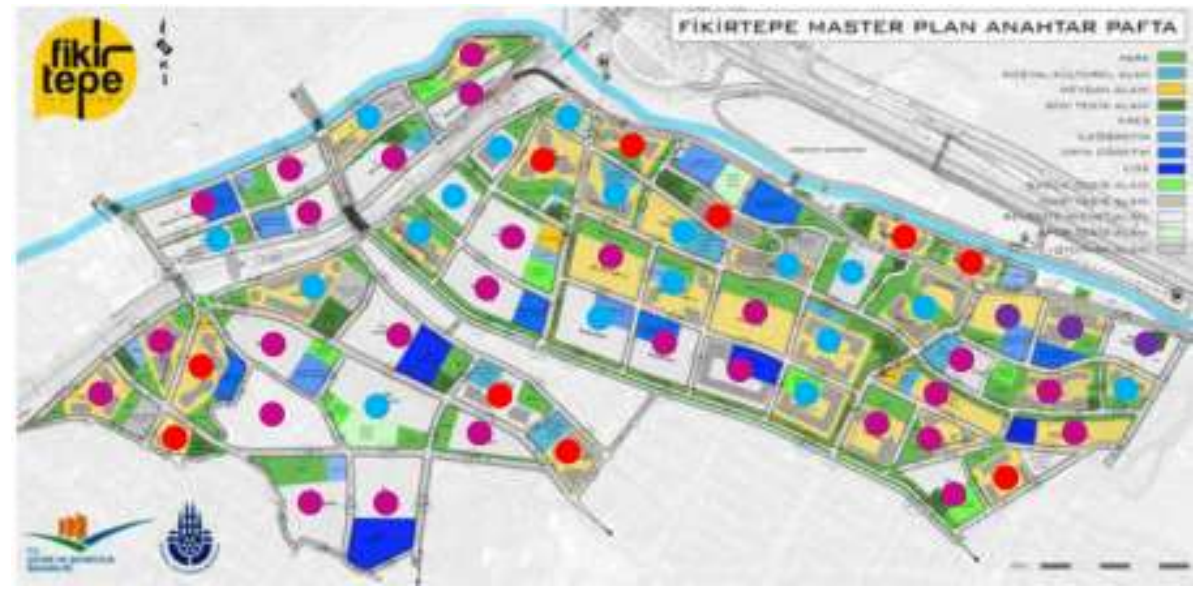

Şekil 7. Fikirtepe Kentsel Dönüşüm Projeleri'ndeki son durum. (Kaynak: Sezer, Z. II. Uluslararası Şehir, Çevre ve Sağlık Konferansı, Nisan 2018 - Ekim 2018'de revize edilmiştir (Diker,B.).

Fikirtepe, İstanbul'da kentsel dönüşümde pilot bölge olarak seçilmiş olması nedeniyle önem arz etmektedir. Konumu itibariyle odak noktası olan ve 134 hektarlık planlama alanı ile dikkat çeken bölgede yapılacak bir iyileştirmenin, daha geniş kitlelere hitap edeceği varsayılmıştır. 


\section{Kabuller ve Sinırlamalar}

Bu çalışma, Fikirtepe'de planlanan yeni konut binalarının çevresel açıdan ne kadar 'sürdürülebilir' olduğunu araştıran bir yüksek lisans tezinden türetilmiştir. Çalışma kapsamında ele alınan proje sayısı, 2019 yılı itibariyle alandaki güncel proje sayısıyla kıyaslandığında az gibi görünse de 2015-2017 yılları arasında ruhsat alıp yapım süreci başlamış veya tamamlanmış olan 17 yeni konut binasının 10 tanesi üzerinden yapılan tez çalışmasının evreni, aynı zamanda bu makalenin de kapsamı olmaktadır.

Seçilen konut binalarının satış süreci devam ettiğinden; isimlerinin kullanılmasından kaçınılmış ve Çok Katlı Konut (ÇKK) 1, 2, 3... olarak isimlendirilmiştir.

Çalışmada belirlenen üç ana başlık dışındaki değerlendirme ölçütleri kapsam dışında tutulmuştur. Ayrıca, sertifikada puan dağılımı yapılmayan ölçütlerde, sıralanan koşulların biri dahi sağlanamamış ise, konunun kapsam ve gerekliliğinin sağlanmadığı kabul edilmiştir (Diker, 2016).

\section{Değerlendirme ve Bulgular}

2016 yılının Ocak ve Şubat aylarında, seçilen on adet konut projesinin her biri için; hazırlanan anket soruları yardımıyla proje ekibi ve yüklenici firmalar ile yüz yüze görüşmeler yapılmıştır. Anketlerdeki değerlendirme ölçütlerine ilişkin soruların hangi paydaşlara yöneltildiğini gösteren çalışma Tablo 5'te verilmiştir:

Tablo 5. Ölçüt bazında anketlerin uygulandığı paydaşlar.

\begin{tabular}{lcc}
\hline Değerlendirme Kriterleri & Proje ekibi & Yüklenici firma \\
\hline Bütünleşik Yeşil Proje Yönetimi (1) & & \\
\hline İnşaat atık yönetimi & & $\mathrm{X}$ \\
\hline Enerji Kullanımı (4) & $\mathrm{X}$ & \\
\hline Enerji Verimliliği & $\mathrm{X}$ & $\mathrm{X}$ \\
\hline Yenilenebilir enerji kullanımı & & $\mathrm{X}$ \\
\hline Enerji verimli beyaz eşyalar & & \\
\hline Malzeme ve Kaynak Kullanımı (6) & $\mathrm{X}$ & $\mathrm{X}$ \\
\hline Çevre dostu malzeme & $\mathrm{X}$ & $\mathrm{X}$ \\
\hline Mevcut bina elemanlarından yararlanılması & $\mathrm{X}$ & $\mathrm{X}$ \\
\hline Malzemenin yeniden kullanımı & $\mathrm{X}$ & $\mathrm{X}$ \\
\hline Yerel malzeme kullanımı & $\mathrm{X}$ & $\mathrm{X}$ \\
\hline Dayanıklı malzeme & &
\end{tabular}


Toplamda 10 konut projesi için 10 adet proje ekibi ve 8 adet yüklenici firma ile görüşülmüş; alınan cevaplar ölçüt bazında incelenmiştir.

'İnşaat atık yönetimi' ölçütüyle ilişkili olarak yüklenici firmaya, yapım sürecindeki atık oluşumunun kontrol altında tutulmasına ilişkin sorular yöneltilmiştir. Yapılan anket çalışmasında "Projenin atık yönetim planı var mı?" sorusuna sekiz firmadan sadece ikisi olumlu yanıt vermiştir (Şekil 8):
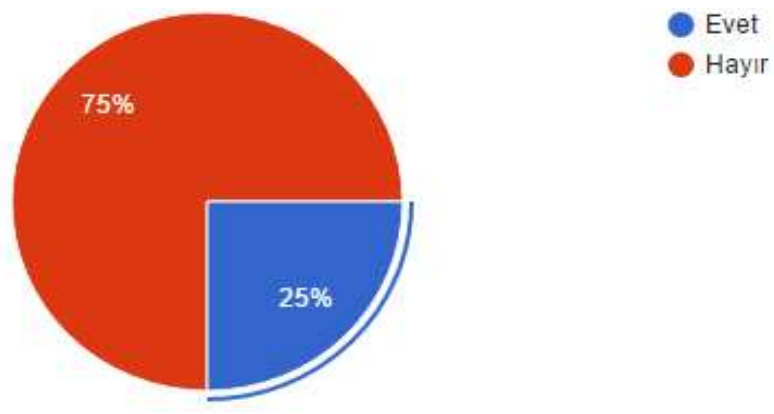

Şekil 8. Firmalarda atık yönetim planı varlı̆̆ı.

Yapılan anket çalışmasında "Atıklar için geri dönüşümlü lisans firmalarıyla anlaşıldı $m \imath$ ?" sorusuna sekiz firmadan sadece üçü olumlu yanıt vermiştir (Şekil 9).

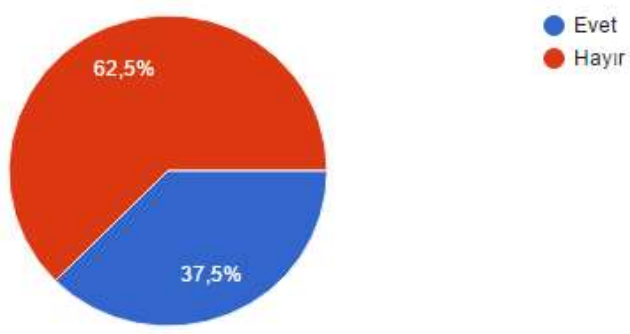

Şekil 9. Firmalarda lisanslı geri dönüşüm firmaları ile anlaşması durumu.

İnşaat sırasında oluşan atıkların bertarafı çoğunlukla yerel belediyeye bırakılmıştır. Atıkların geri dönüştürülerek saha içerisinde yeniden değerlendirilmesi önemli oranda kaynak tasarrufu sağlama imkanına sahip iken tercih edilmemiştir (Diker, 2016).

'Enerji Kullanımı' ile ilgili değerlendirme ölçütünün kapsam ve gerekliliğinin sağlanabilmesi için, binaların enerji performansını- özellikle 1sıtma, soğutma ve aydınlatma yüklerini- ölçen dinamik simülasyon metotlarının kullanılması beklenmektedir. 10 adet konut projesi için proje 
ekipleriyle yapılan görüşmede seçilen konutların hiçbirinde bina enerji modellemesi yapılmadığı tespit edilmiştir (Şekil 10).
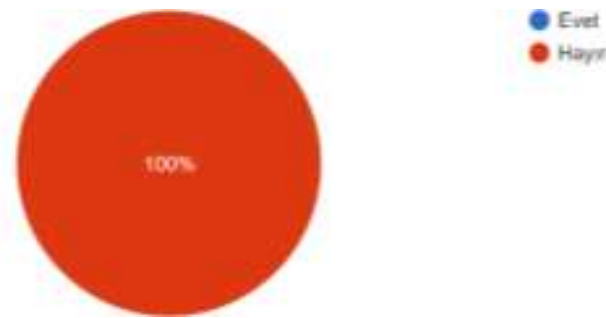

Şekil 10. İncelenen projelerde dinamik simülasyon programlarının kullanımı.

'Yenilenebilir enerji kullanımı' ölçütüne yönelik yüklenici firma ve proje ekibine yönetilen sorularda; yenilenebilir enerji sistemleri için sahada herhangi bir fizibilite çalışmasının yapılıp yapılmadı̆̆ı, kullanılan veya öngörülen yenilenebilir enerji sistemleri, varsa türleri ve sistemlerin karşıladığı enerji tüketim yüzdeleri gibi veriler elde edilmeye çalışılmıştır.

İncelenen projelerin tümünde yenilenebilir enerji olarak güneş enerjisi tercih edilmiştir (Şekil 11). Yapılan görüşmelerde, \%5-10 oranında, binanın ortak alanlarında tercih edilen sistemlerin birincil amacının site aidatlarını düşürmek olduğu belirtilmiştir (Diker, 2016).
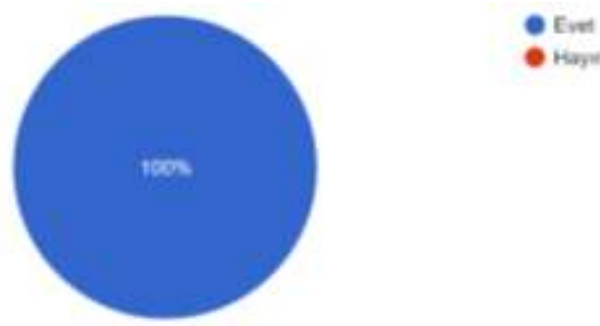

Şekil 11. İncelenen projelerde güneş enerjisi sistemlerinin kullanılma durumu.

Saha dışından yenilenebilir enerji satın alan sadece bir proje bulunmaktadır (Şekil 12). 


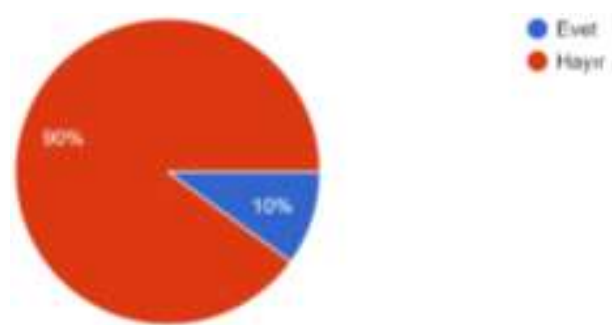

Şekil 12. İncelenen projelerde saha dışından yeşil/yenilenebilir enerji satın alma durumu.

'Enerji verimli beyaz eşyalar' isimli değerlendirme ölçütünde, konut içerisinde bulunan beyaz eşyaların sahip olması gereken enerji sınıfı hakkında bilgi verilmektedir. Konut içerisindeki beyaz eşyalar kullanıcılar tarafından karşılanıyorsa; cihazların A veya daha üst bir enerji sınıfından seçilmesi gerektiği konut satış sözleşmesine eklenmelidir (ÇEDBİK Konut Sertifika Kılavuzu, 2015).

Bu ölçütle ilgili incelenen projelerde, konut içerisindeki beyaz eşyaların temini çoğunlukla kullanıcıya bırakılmış; buna karşın konut satış sözleşmesinde alınacak beyaz eşyaların enerji sınıfına ilişkin bağlayıcı bir madde eklenmemiştir (Diker, 2016).

'Malzeme ve Kaynak Kullanımı' isimli değerlendirme ölçütü kapsamında, yüklenici firmalardan, inşaatta kullanılan malzemelerin çevresel ürün beyanı bulundurup bulundurmadığı hakkında bilgi alınması hedeflenmiştir.

Yapılan anket çalışmasında hem proje ekibi hem de yüklenici firmalara yöneltilen "İnşaatta kullanılan malzemelerin çeoresel ürün beyanı, EU ECO LABEL, EPD, NATUREPLUS, CE, DIN, FSC, PEFC gibi (eko-etiket) gibi çeore etiketi bulunmakta mıdır?" sorusuna yedi adet olumlu yanit gelmiştir. Bu yedi firma, yapı iskeletinde, çatıda, dış duvar ve giydirme cephede, iç bölücü duvarlarda, döşeme ve kaplamalarda, kapı, pencere doğramalarında çevre etiketinin bulunduğunu ya da öngörüldüğünü belirtmiştir (Şekil 13).

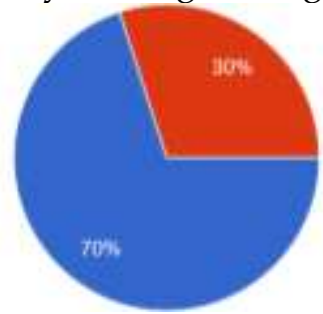

Hing

Şekil 13. İncelenen projelerde çevre dostu malzeme kullanılması durumu. 
'Mevcut bina elemanlarından yararlanılması' isimli değerlendirme ölçütünde gereksiz kaynak kullanımını önlemek ve atıkları azaltmak amacıyla mevcut bina elemanlarının kullanılması öngörülmektedir (ÇEDBIKK Konut Sertifika Kılavuzu, 2015).

Ancak incelenen projelerin hiçbirinde mevcut bina elemanlarından yararlanılmadığı belirtilmiştir (Şekil 14). Bunun nedeni, Fikirtepe'nin yıllar içinde geçirdiği hızlı kentleşme sonrası niteliksiz yapı stoğuna sahip olması olarak düşünülebilir.
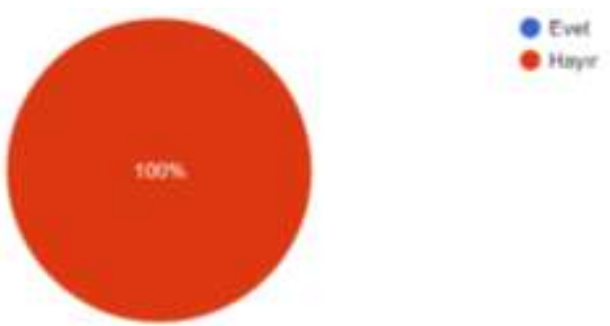

Şekil 14. İncelenen projelerde mevcut bina elemanlarının kullanılması durumu.

'Malzemenin yeniden kullanımı' isimli değerlendirme ölçütünde, inşaatın çevresel etkilerini minimize edebilmek adına proje ekiplerinin; kılavuzdaki tanımıla "10 yıl veya daha kısa sürede sürdürülebilir bir şekilde büyüyüp yetişebilen veya üretilebilen tarm ürünleri" olarak belirtilen 'yenilenebilir malzeme' kullanımını öngördügü bir yaklaşımın varlığı sorgulanmıştır (Diker, 2016).

İncelenen projelerde yenilenebilir malzemelerin çoğunlukla tercih edilmediği görülmüştür (Şekil 15).
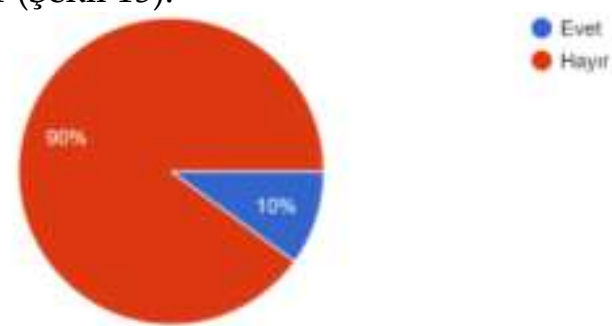

Şekil 15. Geri dönüşümlü ve yenilenebilir malzeme kullanım durumu.

'Yerel malzeme kullanımı' isimli değerlendirme ölçütündeki ana hedef, nakliye sırasındaki karbon salım miktarını ve kaynak kullanımını azaltmaktır (ÇEDBİK Konut Sertifika Kılavuzu, 2015). 
Görüşme yapılan firmaların çoğu inşaatta 100- 400 km sınırları içerisinden temin edilen yerel malzemeleri tercih etmektedir (Şekil 16). Böylelikle, nakliye sırasındaki karbon salım miktarı azaltılarak gereksiz kaynak tüketimi önlenmektedir.
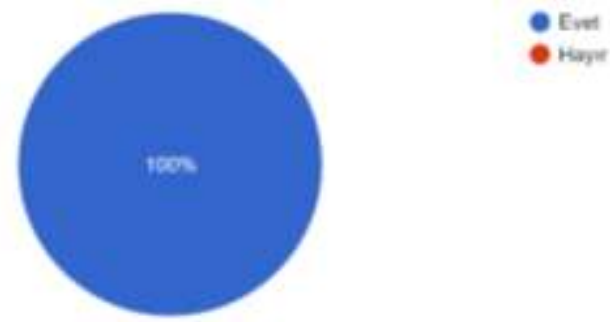

Şekil 16. İncelenen projelerde yerel malzeme kullanılma durumu.

'Dayanıklı malzeme' isimli değerlendirme ölçütü kapsamında yüklenici firmalara, inşaatta kullanılan malzemelerin dayanıklılığı ve servis ömrü ile ilgili sorular yöneltilmiştir.

İncelenen projelerin hiçbiri, yapı kabuğunda kullanılan malzemelerin servis ömrü ile ilgili gerekliliği sağlayamamıştır (Şekil 17). (Periyodik bakım hariç en az 30 yıl garanti süresi istenmektedir).

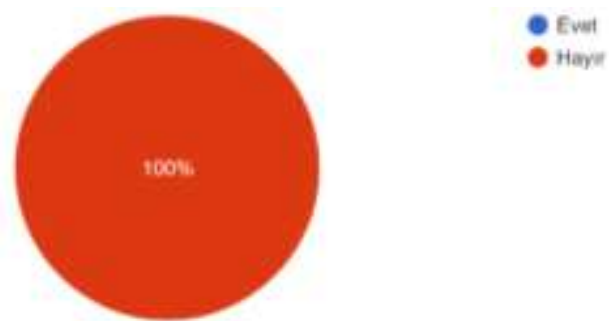

Şekil 17. İncelenen projelerde dayanıklı malzeme kullanılma / minimum hizmet ömrünü sağlama durumu.

\section{Sonuç}

Bu çalışmada, Fikirtepe Kentsel Dönüşüm Alanı'nda yapım süreci başlamış veya tamamlanmış olan yeni konut binalarının çevresel sürdürülebilirlik açısından farkındalığı araştırılmıştır. Bu kapsamda, ÇEDBİK Konut Sertifikası bir değerlendirme aracı olarak ele alınmış ve sertifikada belirtilen ölçütlerden; Bütünleşik Yeşil Proje Yönetimi, Enerji Kullanımı ile Malzeme ve Kaynak Kullanımı başlıklı ölçütleri incelenmek üzere seçilmiştir. 
Sertifikada belirlenen ölçütlerin kapsam ve gerekliliklerinin sağlanabilmesi için gerekli şartlar incelenmiş; bu şartların yerine getirilip getirilmediğinin ölçülebilmesi için anket yöntemine başvurulmuştur. Anketlerde ulaşılmak istenen verilerin kimlerden alınabileceğine yönelik ise ölçüt bazında bir çalışma yapılmıştır. Verilerin elde edileceği paydaşların iki ana gruba indirgenmesinin ardından, çalışma kapsamında seçilen 10 adet konut projesinin her biri için, proje ekibi ve yüklenici firmalar ile yüz yüze görüşmeler gerçekleştirilmiş ve ilgili kişilere daha önceden hazırlanan anket soruları yöneltilmiştir. Alınan cevaplar doğrultusunda ise ölçüt bazında uygunluk kontrolleri yapılmış ve elde edilen bulgular tablo ve grafiklerle yorumlanmıştır.

Paydaşlarla yapılan görüşmeler neticesinde elde edilen verilerin, her bir alt ölçüte ilişkin gerekli koşulları sağlayıp sağlayamadığına ilişkin oluşturulan özet veri çizelgesi Ek-1'de daha detaylı olarak verilmiştir. Bu çizelgeye göre;

- Atıkların değerlendirilmesi veya yönetimi konusuna verilen önem oldukça azdır.

- Enerji verimliliği başlığı altında incelenen ve binaların enerji performansını ölçmeyi amaçlayan dinamik simülasyon araçlarının kullanımına hiçbir projede rastlanmamıştır.

- Yenilenebilir enerji kullanımı konusunda özellikle güneş enerjisi kullanımının yaygın olduğu görülmüştür. Verilen cevaplarda, bu sistemlerin çoğunlukla inşaat alanının \%5-10 'una denk gelen ortak alanlarda, aidat giderlerini azaltma amacı ile uygulandığ ulaşılmıştır.

- Yatırımcı ve kullanıcı arasında yapılan sözleşmelerde konutlarda kullanılan beyaz eşyaların enerji sınıfları ile ilgili bağlayıcı bir madde bulunmadığı görülmüştür.

- İncelenen konut binalarında kullanılan malzemelerin çoğunlukla 100 km sinırları içerisinden seçilmiş olması; gereksiz nakliye ihtiyacını ortadan kaldırması ve sera gazı salımını azaltması sebebiyle olumlu bulunmuştur.

- İncelenen alandaki mevcut yapı stoku niteliksiz olduğundan "Mevcut bina elemanlarından yararlanılması" isimli ölçütteki gereklilikler sağlanamamıştır.

Sonuç olarak, Fikirtepe Kentsel Dönüşüm Alanı'nda yapılan değerlendirmede, planlanan yeni konut binalarının çevresel sürdürülebilirlik aç1sından birtakım eksikleri olduğu tespit edilmiştir. Türkiye'nin İDEP 2023 
bina sektörü hedeflerine ulaşabilmesi için, özellikle bina üretiminin yoğunlaştığı kentsel dönüşüm alanlarından başlamak üzere; yeni yapılacak tüm konutlarda bina enerji performansını geliştirici hedefler koyması gerekmektedir. Bu bağlamda, ulusal konut sertifikasının yeni konut binaları için zorunlu tutulmasının, hedeflere ulaşılabilirliği kolaylaştıracağı düşünülmektedir. Buna ilave olarak, binalarda 1sıtma, soğutma ve aydınlatma yüklerinin hesabında kullanılan ve bina enerji performansını ölçen dinamik simülasyon araçlarının da bu bağlamda ele alınması gereklidir.

Ayrıca, binalarda enerji verimliliği konusunda $A B$ ülkelerinin örnek alınması ve güncel yasal mevzuatın geliştirilmesinin ötesinde, yapılan uygulamalarda denetim mekanizmasının da iyileştirilmesi gerekmektedir. 


\title{
Extended Abstract
}

\section{A Research on Environmental Sustainability in Urban Transformation: The Case of Fikirtepe \\ *}

\author{
Begüm Diker \\ İstanbul Doğuş University \\ ORCID: 0000-0001-9149-3880
}

Urbanization has been shaped according to the needs of each period and society, but it has gain speed, especially with the influence of industrialization in the 19th century. Due to the migration from rural to the urban, population of cities has increased gradually. According to the United Nations report, by 2050, two-thirds of the human population in the world is estimated to live in cities. While the number of people living in cities in Turkey is about $75 \%$ in 2018, the ratio for 2050 is projected to be like $86 \%$.

One of the main effects of urbanization on the environment is global warming. The increase in energy and resource consumption due to human activities triggers climate change. Similarly, increased energy consumption and decreased natural sources caused by climate change threaten the environment. To prevent this cyclic destruction, in tackling climate change, many world countries have proceeded through to be a 'sustainable city' by setting goals for their local conditions. In this context, 'Green Cities Index' series started by Economist Intelligence Unit in 2009, can be thought as a milestone for assessment of sustainabilities and measurement the performance of cities. According to the report which has contributed by more than 20 organizations including well-known universities such as Harvard and Cambridge, it can be possible to create a sustainable city with the improvements about $\mathrm{CO} 2$ emissions, energy, building, land use, transportation, water and health, waste management, air quality, and environmental management. Also, the grant scheme handled by United Nation 
within the frame of 'Horizon 2020: Smart Cities' supports the organizations and researchers in the field such as 'Sustainable Cities, 'Smart Buildings,' Urban Transformation,' 'Innovation in Construction Sector.'

Turkey follows other world nations in tackling climate change. One of the studies in these contexts is the report called 'Climate Change National Action Plan 2011-2023' prepared by the Ministry of Environment and Urbanisation in 2012 .

In this report, objectives related to energy, building, industry, transportation, waste sectors have been determined. For the building sector, there are some objectives such as "increasing the renewable energy use in buildings" and "decreasing greenhouse gas emissions in new settlements by $10 \% "$. It is essential to make assessments on energy efficiency in the Mega Cities where the population is increasing in the context of reaching these targets. Unfortunately, there is no detailed research on İstanbul, which is known a megacity for Turkey.

In this research, it was desired to draw attention to the share of buildings in the creation of a sustainable city by focusing on energy efficiency in the buildings. In the scope of the study, Fikirtepe, which is prominent as an area where building production is increased due to urban transformation in the city of Istanbul, which is defined as Mega City has been discussed. It is aimed to carry out an environmental sustainability analysis for energy and natural source use and waste management through the construction of new residential buildings which are completed/ incompleted by focusing on the urban transformation project in the region.

The study has four chapters. In the first chapter, a literature review has been done on sustainability and energy efficiency. In this context, current legislation in Turkey has been examined, and the regulations and the standards have been emphasized. Then, the building certification systems in Turkey and the other countries have been summarized for the assessment of building performance. A comparison has made out of the most known certification systems in Turkey. These are; 'ÇEDBİK (Çevre Dostu Binalar Derneği) Residential Certification System, 'SEEB-TR' and 'TSE Green Building Certificate.

In the second chapter, due to the Green Residential Certificate was accepted as a reference between the Ministry of Environment and Urban Planning and ÇEDBIKK and a protocol was signed to carry out the certifi- 
cate works with this association, it has been focused on ÇEDBİK Residential Building Certificate. The criteria contained the subject of energy, resource use, and waste management have been explained in detail.

The third chapter forms the methodological framework of the study. Firstly, the scope and requirements of the subject have been examined for each evaluation criteria in the certificate. A detailed analysis has been made about data can be provided from whom and by which method. In the next step, face-to-face talks are held with stakeholders involved in the design and construction process over ten new residential buildings which are selected in Fikirtepe. The residential building certificate has accepted as an assessment tool, and the answers have been obtained for both stakeholders through questionnaires prepared.

In the last chapter, in the direction of the obtained data, the awareness of the energy and resource use and waste management of the new residential buildings in the pilot region Fikirtepe has been examined. Requirements have evaluated based on each criterion, and the findings have been supported by charts and graphs.

As a result, it has been determined that the new residential buildings planned in Fikirtepe Urban Regeneration Area have some deficiencies in terms of accessibility to IDEP 2023 Building Sector targets. It is thought that these targets are hard to reach because the residential certificate is not mandatory for new buildings in Turkey. Concerning energy efficiency in buildings, beyond the development of the EU legislation and taking the example of the EU countries, it is also necessary to improve the control mechanism in the applications.

\section{Kaynakça/References}

Alkin, E., ve İlkin , A. (1991). Ekonomik ve Sosyal Sorunlar-Çözüm Önerileri Dizisi 1: Çevre sorunları. Ankara: TOBB Yayınları.

Aydın, K. T. (2013). Yeşil bina sertifikasyonları kapsamında yerel sistem gerekliliğinin değerlendirilmesi. Yüksek Lisans Tezi, YÖK Ulusal Tez Merkezi. (Tez no: 346494)

Bayraktar, E. (2007). Bir insanlık hakkı konut: Toki'nin planlı kentleşme ve konut üretim seferberliği. İstanbul: Boyut matbaacilı.

Çepel, N. (1995), Çevre koruma ve ekoloji terimleri sözlüğ̈̈: Türkçe, Almanca, İngilizce. İstanbul: TEMA Vakfı Yayınları. 
Çevre Dostu Binalar Derneği. (2018). ÇEDBIKK- konut sertifika kulavuzu: yeni konutlar V.1. 10 Kasım 2018 tarihinde https://cedbik.org/static/media/page/12/attachments/edbik-konut-sertifika-kilavuzu-2018-v-1-06-06-

2018.pdf? $v=060618014756$ adresinden erişildi.

Çevre Dostu Binalar Derneği [ÇEDBIK]. (2015). ÇEDBIKK-konut sertifika kılavuzu: yeni konutlar versiyon 3.0. 10 Kasim 2018 tarihinde https://docplayer.biz.tr/10518756-Cedbik-konut-sertifika-kilavuzu.html adresinden erişildi.

Çevre ve Şehircilik Bakanlığı [ÇŞB]. (2011, Temmuz). İklim değişikliği ulusal eylem planı 2011-2023. Ankara. 10 Kasım 2018 tarihinde http://www.dsi.gov.tr/docs/iklim-degisikligi/ideptr.pdf?sfvrsn=2 adresinden erişildi.

Çevre ve Şehircilik Bakanlığı [ÇŞB]. (2013). Fikirtepe kentsel tasarım çerçevesi.

Çevre ve Şehircilik Bakanlığı [ÇŞB]. (2013). Kadıköy ilçesi Fikirtepe ve çevresi 1/1000 ölçekli uygulama imar planı değiş̧ikliği plan açıklama raporu. 10 Kasım 2018 tarihinde https://docplayer.biz.tr/36184538-Kadikoy-ilcesi-fikirtepe-vecevresi-1-1000-olcekli-uygulama-imar-plani-degisikligi-plan-aciklamaraporu.html adresinden erişildi.

Diker, B. (2016). Kentsel dönüşüm kapsaminda konutlarda ulusal yeşil bina değerlendirme sistemleri: Fikirtepe örneği. Yüksek Lisans Tezi, YÖK Ulusal Tez Merkezi. (Tez no: 450958)

Gürlesel, C.F. (2012, Mayıs). 2023 Vizyonunda gayrimenkul sektörü. İstanbul: Stil Matbaacilik.

Karabalık, K. ve Özyurt, G. (2009). Enerji Verimliliği, Binaların Enerji Performansı ve Türkiye'deki Durum. TMMOB, İnşaat Mühendisleri Odası, Türkiye Mühendislik Haberleri, 457(54), 32-34.

World Commission on Environment. (1987). Our common future. 10 Kasim 2018 tarihinde https://sswm.info/sites/default/files/reference attachments/UN\%20WCED\%201987\%20Brundtland\%20Report.pdf adresinden erişildi.

Ünlü, H. (1991). Yerel yönetim ve çevre el kitabı. İstanbul: IULA -EMME.

Worldwatch Enstitüsü. (2016). Dünyanın durumu 2016: Bir kent sürdürülebilir olabilir mi? (D. Kutluay, Çev.) İstanbul: Türkiye İş Bankası Kültür Yayınları.

Prugh, T. ve Renner,M. (2016). Kentler ve sera gazı emisyonları: sorunun boyutları. (L. Mastny, Edi.). Dünyanin durumu 2016: bir kent sürdürülebilir olabilir mi? içinde. (s. 91-105) İstanbul: Türkiye İş Bankası Kültür Yayınları.

Renner, M. (2016). Binaların çevresel ayakizini azaltmak. (L. Mastny, Editör). Dünya'nın durumu 2016: bir kent sürdürülebilir olabilir mi? (s.137-159) İstanbul: Türkiye İş Bankası Kültür Yayınları.

Siemens. (2010). Sürdürülebilir şehirler: şehirler için sürdürülebilir gelişme. 01 Ekim 2018 tarihinde http://www.siemens.com.tr/i/Assets/surdurulebilir_sehirler/SurdurulebilirSehir\%20ic.pdf adresinden alındı. 
HORIZON 2020 Akıllı Şehirler (Smart Cities) 2018 yılı Proje Çağrıları açıldı I Resmi Tescilli UFUK 2020. (t.y.). 3 Ekim 2018 tarihinde http://www.ufuk2020.com/haberler/horizon-2020-akilli-sehirler-smart-cities-2018-cagrilari-acildi.html adresinden alındı.

Ek-1. Özet veri çizelgesi (Diker, 2016). 


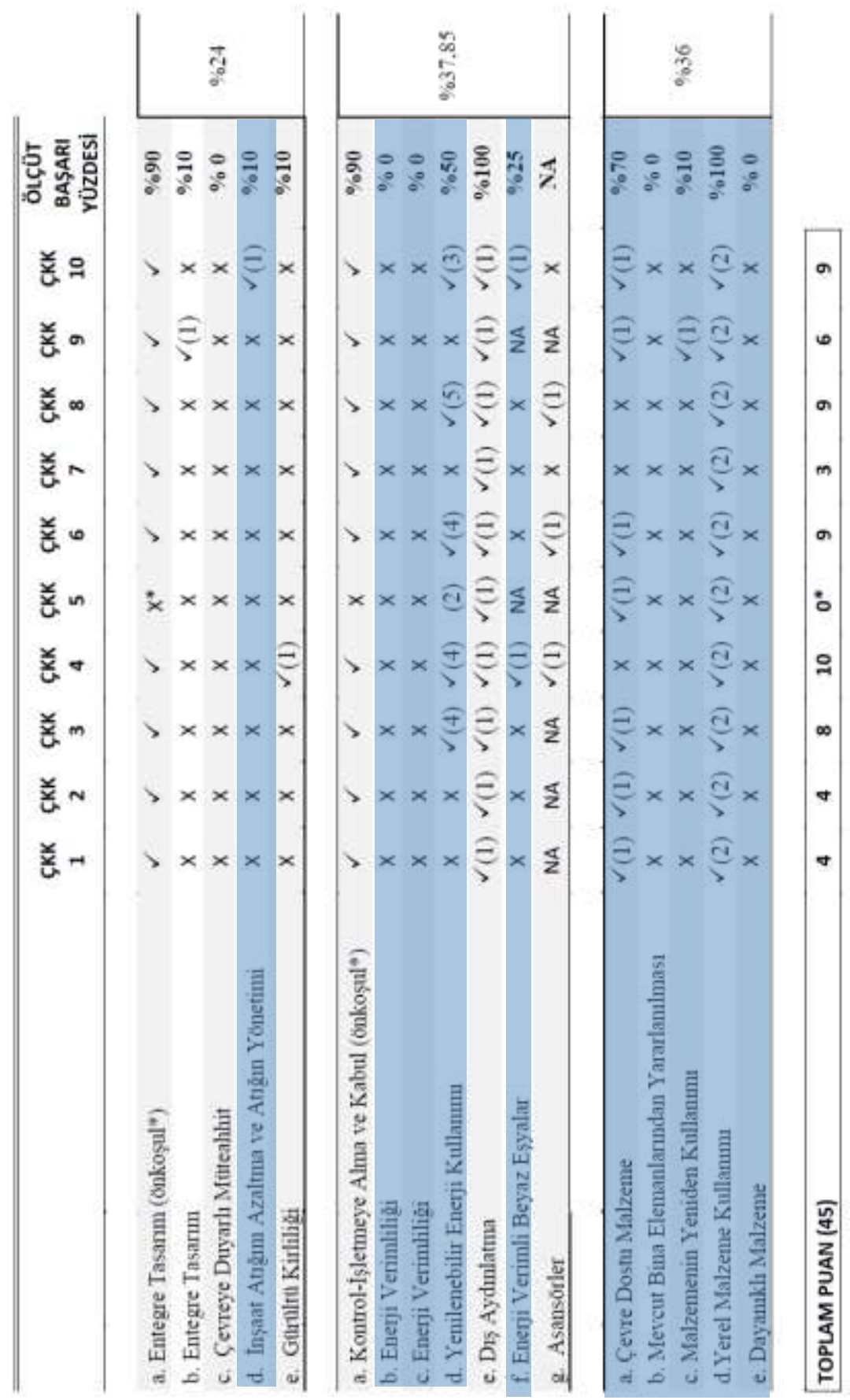

Ek-2. Proje Ekibi/ Müellifi Anket Soruları (Diker, 2016). 
Bu anket İstanbul Teknik Üniversitesi Mimarlık Ana Bilim Dalı, Çevre Kontrolü ve Yapı Teknolojisinde yapılan bir yüksek lisans çalışması için akademik amaçlı yapılmaktadır. Burada vereceğiniz yanıtlar yalnızca akademik amaçlı kullanılacaktır. Kişisel bilgi edinme amacı yoktur. Verdiğiniz destek için çok teşekkür ederiz.

Proje adı : $\quad$ Yanitlayan :

\section{ENERJI VERIMLİLİĞİ- ÖNKOŞUL}

1. Binanın enerji performansını ölçmek için enerji modellemesi yapıldı mı?

$\square$ Evet Hayir $\square$

(Enerji modellemesi yapılmadıysa 2. ve 3. soruları geçiniz.)

Enerji danışmanlığı firma ismi

2. Modelleme yapıldı ise hangi hesaplama metodu kullanılmıştır?

BEP-TR (Ulusal Bina Enerji Performansı Hesaplama Yöntemi) Enerji Sınıfı: Energy-Plus

\section{Design Builder}

\section{DOE-2}

Diğer (Açıklayınız)

- Önerilen binada kullanım takvimlerine bağlı olarak ısıtma ve soğutma ayar sıcaklıklarını sağlamayan saatlerin toplamı 300 saat/yıl'ı aşmamalıdır.

- 2- Enerji performansı ağırlıklı iyileştirme oranı en az \%6 olmalıdır.

3. Yapılan simülasyon sonucunda binanın enerji performansı ağırlıklı iyileştirme oranı nedir?

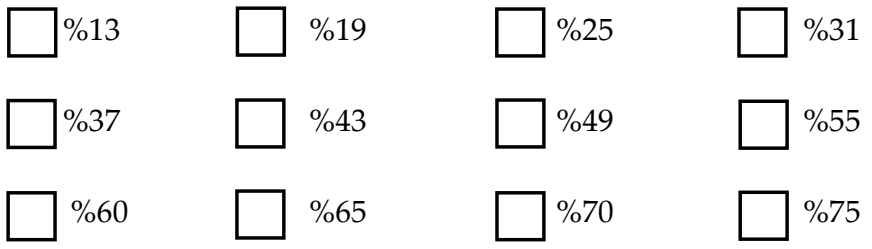

\section{YENILENEBİLİR ENERJİ KULLANIMI}

1. Yenilenebilir enerji teknolojileri için fizibilite çalışması yapıldı mı? (2) (Güneş, rüzgar, jeotermal, küçük kapasiteli Hidro enerjisi, biyokütle ve biyogaz vb.) Evet Hayır

2. Sahada güneş enerjisi, rüzgâr enerjisi jeotermal enerji gibi yenilenebilir enerji teknolojileri kullanılıyor mu? (1-5) 
Evet Hayır

Evet ise; yenilenebilir enerji sisteminden karşılanan oranı seçiniz.

$\% 2 \quad \% 5 \quad \% 10 \quad \% 20 \quad \% 30$

3. Saha dışından yenilenebilir enerji satın alınacak mı? (1-3) (Kontrat yapılması gerekir.)

Evet Hayır $\square$

ÇEVRE DOSTU MALZEME KULLANIMI

1. İnşaatta kullanılan malzemelerin çevresel ürün beyanı, EU ECO LABEL, EPD, NATUREPLUS, CE, DIN, FSC, PEFC gibi (eko - etiket) gibi çevre etiketi bulunmakta mıdır?

Evet

Hayır

\section{MALZEMENIN YENIDEN KULLANIMI (4)}

1. Binada geri dönüşümlü, çabuk yenilenebilen dayanıklı malzemeler kullanıld1 mi?

$\square$ Evet

Evet ise;

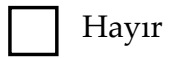

$\square$ Yapı iskeleti, çatı duvar, iç duvar, döşeme, kapı pencere doğramaları gibi yapı elemanlarından \%15inin yeniden kullanılan malzeme olması (1)

Yapı elemanlarının en az \%2,5 oranında yenilenebilir veya geri dönüştürülmüş hammadde içerikli malzeme olması (1)

Kullanılan agreganın \%20'si geri kazanılmış olmalı, sahaya maksimum 50 km uzaklıktan getirilmiş olması. (1)

2. Binada kullanılan orman ürünleri ve türevi malzemelerinde Orman Genel Müd., FSC veya PEFC sertifikası var mıdır?

$\square$

Evet

Hayır

\section{YEREL MALZEME KULLANIMI}

1. Projede kullanılan malzemeler ne kadar uzaklıktan temin edilmektedir? (\% kaçı ne kadar uzaklıklıktan temin edilmekte yazınız.) $100 \mathrm{~km}$ sınırları içinden (en az \%10'u)

00km sınırları içinden (en az \%30'u ) 


\section{DAYANIKLI MALZEME}

1. Giriş holü, merdiven, bina içi otoparklar gibi ortak alanlar yıpranmaya karşı korunuyor mu? (1) (Tekmelik- kolay temizlenebilir döşeme kaplaması, otoparklarda duvar ve kolon koruyucuları)

Evet $\square$ Hayır

2. Cephede kullanılan yapı elemanlarının servis ömrü/garanti süresi ne kadardır?

ए $0-10 \mathrm{yll}$

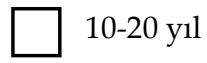

MEVCUT BİNA ELEMANLARINDAN YARARLANILMASI

1.Mevcut bina elemanlarının bir kısmı veya tamamı yeni binada kullanılmış mıdır?

$\square$ Evet<smiles>[Mg][GeH3]</smiles>

Evet ise;

Bina cephesi ve taşıyıcı sistemin \%50si aynen bırakılıp diğer bölümlerin yenilenmesi

Bina cephesi ve taşıyıcı sistemin aynen bırakılıp yalnızca iç kaplamaların yenilenmesi.

Ek-3: Yüklenici firma anket soruları.

Proje adı : Yanitlayan :

\section{INSSAAT ATIĞINI AZALTMA VE ATIĞIN YÖNETIMI}

1. İnşaat sırasında ortaya çıkan hafriyat, moloz, ambalaj atı̆̆ı, cam, plastik, metal vb. ürünler sahada yeniden kullanılıyor mu? (A ğırlık veya hacim olarak \%45)

Evet

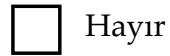

2. Atıklar için lisanslı geri dönüşüm firmaları ile anlaşıldı mı?

Evet

Hayır

\section{YENILENEBİLIR ENERJI KULLANIMI}

4. Yenilenebilir enerji teknolojileri için fizibilite çalışması yapıldı mı? (2) (Güneş, rüzgâr, jeotermal, küçük kapasiteli Hidro enerjisi, biyokütle ve biyogaz vb.) Evet Hayır 
5. Sahada güneş enerjisi, rüzgar enerjisi jeotermal enerji gibi yenilenebilir enerji teknolojileri kullanılıyor mu? (1-5)

Evet

Hayır

6. Saha dışından yenilenebilir enerji satın alınacak mı? (1-3) (Kontrat yapılması gerekir.)

Evet

Hayır

\section{ENERJI VERIMLII BEYAZ EŞYALAR}

1. Konut içerisindeki beyaz eşyaların (çamaşır mak., bulaşık mak. ve buzdolabı) teminini kim sağlamaktadır?

Yatırımc1

Kullanicı

2. Yatırımcı temin etmekte ise seçilen cihazların enerji sınıfları nedir?

A

$\mathrm{A}+$

$\square \mathrm{B}$

$\square \mathrm{C}$<smiles>C1CCC1</smiles>

Diğer.

\section{ÇEVRE DOSTU MALZEME KULLANIMI}

İnşaatta kullanılan malzemelerin çevresel ürün beyanı, EU ECO LABEL, EPD, NATUREPLUS, CE, DIN, FSC, PEFC gibi (eko-etiket) gibi çevre etiketi bulunmakta mıdir?

$\square$ Evet $\square$ Hayır

Evet ise; değerlendirilen yapı elemanlarında çevre etiketi bulunan malzemeleri belirtiniz.

\section{MALZEMENIN YENIDEN KULLANIMI (4)}

3. Binada geri dönüşümlü, çabuk yenilenebilen dayanıklı malzemeler kullanild1 mi?

$\square$ Evet

Evet ise; Hayır

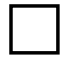

Yapı iskeleti, çatı duvar, iç duvar, döşeme, kapı pencere doğramaları gibi yapı elemanlarından \%15inin yeniden kullanılan malzeme olması (1)

Yapı elemanlarının en az \%2,5 oranında yenilenebilir veya geri dönüştürülmüş hammadde içerikli malzeme olması (1)

Kullanılan agreganın \%20si geri kazanılmış olmalı, sahaya maksimum 50km uzaklıktan getirilmiş olması. (1) 
4. Binada kullanılan orman ürünleri ve türevi malzemelerinde Orman Genel Müd., FSC veya PEFC sertifikası var mıdır?

Evet Hayır

\section{YEREL MALZEME KULLANIMI}

2. Projede kullanılan malzemeler ne kadar uzaklıktan temin edilmektedir? (\% kaçı ne kadar uzaklıklıktan temin edilmekte yazınız.)

$\square 100 \mathrm{~km}$ sinırları içinden (en az \%10'u)

$\square$ 00km sinırları içinden (en az \%30’u )

\section{DAYANIKLI MALZEME}

3. Giriş holü, merdiven, bina içi otoparklar gibi ortak alanlar yıpranmaya karşı korunuyor mu? (1) (Tekmelik- kolay temizlenebilir döşeme kaplaması, otoparklarda duvar ve kolon koruyucularl)

$\square$ Evet $\square$ Hayır

4. Cephede kullanılan yapı elemanlarının servis ömrü/garanti süresi ne kadardir?

$\square \quad 0-10 \mathrm{yll}$

$\square$ 10-20 y1l

Cephede kullanılan yapı elemanları marka

\section{MEVCUT BİNA ELEMANLARINDAN YARARLANILMASI}

1.Mevcut bina elemanlarının bir kısmı veya tamamı yeni binada kullanılmış mıdır? Hayır

Evet ise;

Bina cephesi ve taşıyıcı sistemin \%50si aynen bırakılıp diğer bölümlerin yenilenmesi

Bina cephesi ve taşıyıcı sistemin aynen bırakılıp yalnızca iç kaplamaların yenilenmesi 
Begüm Diker, 2013 yılında Kocaeli Üniversitesi Mimarlık bölümünden mezun olmuştur. 2014 senesinde başladığı İstanbul Teknik Üniversitesi Çevre Kontrolü ve Yapı Teknolojisi yüksek lisans programını 2017 yılında tamamlamıştır. 2018 yılından itibaren İstanbul Teknik Üniversitesi Mimarlık Ana Bilim Dalı, Yapı Bilimleri doktora programında çalışmalarına devam etmektedir. Aynı zamanda, Doğuş Üniversitesi Sanat ve Tasarım Fakültesi Mimarlık Bölümü'nde araştırma görevlisi olarak çalışmaktadır. İlgi alanları arasında; ekolojik tasarım, binalarda enerji verimliliği, sıfır enerji binalar, sürdürülebilir kentsel dönüşüm bulunmaktadir.

Begüm Diker graduated from Kocaeli University, Department of Architecture in 2013. She started to master program in Istanbul Technical University, Environmental Control and Building Technology program in 2014 and completed in 2017. Since 2018, she is continuing her PhD. studies in Construction Sciences program in the department of Architecture, Istanbul Technical University. At the same time, she is working in Doğuş University, Faculty of Art and Design, Department of Architecture as a research assistant. Her research interests are: ecological design, energy efficiency in buildings, zero-energy buildings, sustainable urban renewal.

E-mail: bdiker@dogus.edu.tr 